\title{
Stretching the Archives
}

\section{Ego-documents and Life Writing Research in the Netherlands: State of the Art}

LEONIEKE VERMEER

This review article offers an overview of ego-documents and life writing research in the Netherlands. It discusses the outcomes of extensive national archival projects aimed at establishing inventories of ego-documents held in Dutch public archives (diaries, memoirs, personal letters and other forms of autobiographical writing) from the period of 1500 until 1918. The most important research lines and debates on ego-documents, auto/biography and life writing are evaluated and linked to issues of disciplinary demarcation between literary scholars and historians. Developments in the last few decades point towards increasing collaboration between these disciplines, which is also needed to face the challenges and opportunities presented by digitisation. The online databases of ego-documents from the inventory projects are very valuable but have several downsides: they are far from complete and often not user-friendly or searchable by keyword. Furthermore, greater efforts should be made to stretch the archive beyond its traditional limitations and shed light on groups and perspectives that have been underexposed in history. This conclusion is also relevant to printed editions of ego-documents. These editions are welcomed, but could pay more attention to a greater diversity of authors and experiences, as well as to the visual and material quality of the sources.

Dit artikel biedt een overzicht van het Nederlandse onderzoek naar egodocumenten en life writing. Het brengt de resultaten in kaart van de omvangrijke inventarisatieprojecten van egodocumenten (dagboeken, memoires, persoonlijke brieven en andere autobiografische teksten) uit de periode 15001918 die in Nederlandse openbare archieven bewaard worden. De belangrijkste onderzoekslijnen en discussies over egodocumenten, auto/biografie en life writing worden in dit artikel beoordeeld en in verband gebracht met de institutionele 
afbakening tussen literatuurwetenschappers en historici. De ontwikkelingen in de afgelopen decennia wijzen op een toenemende samenwerking tussen deze disciplines, die ook nodig is vanwege de uitdagingen en mogelijkheden die digitalisering met zich meebrengt. De online databanken van egodocumenten die zijn voortgekomen uit de inventarisatieprojecten zijn zeer waardevol, maar hebben ook enkele keerzijden: ze zijn verre van compleet en vaak niet gebruikersvriendelijk of doorzoekbaar op trefwoord. Bovendien zijn er grotere inspanningen vereist om de traditionele beperkingen van de bestaande publieke archieven te overstijgen zodat er meer oog komt voor groepen en perspectieven die in de geschiedschrijving onderbelicht zijn gebleven. Deze conclusie is ook relevant voor uitgegeven egodocumenten. Deze uitgaven zijn van grote waarde, maar ze zouden een grotere diversiteit aan auteurs en ervaringen kunnen weerspiegelen en meer aandacht moeten schenken aan de visuele en materiële vorm van deze bronnen.

\section{Introduction}

The historiography on (auto)biographical writing in the Netherlands has led to contradictory statements. On the one hand, scholars have observed the absence of autobiographical and biographical traditions. They attribute this to the alleged taboo in Dutch Protestantism on the public discussion of a private life (biography) and a distaste for excessive attention to the self (autobiography). ${ }^{1}$ On the other hand, historians have argued that autobiographical writing in the Netherlands has developed similarly to its neighbouring countries and therefore fits into a West-European pattern, marked by a sharp rise in the number of ego-documents after 1780 which continued in the nineteenth century. ${ }^{2}$ This last conclusion seems more valid, as it is based on the latter scholars' extensive inventory projects covering all ego-documents held in Dutch public archives (diaries, memoirs, personal letters and other forms of autobiographical writing), both manuscripts and printed texts dating from the period $1500-1918$. These inventory projects were executed by the Dutch historians Rudolf Dekker, Arianne Baggerman, Hans Valk and others during the 1980 .

In this review article, I will evaluate these inventory projects and their outcomes, in print and in online form, and place them in the broader context

in: Erin Griffey (ed.), Envisioning Self and Status: Self-Representation in the Low Countries 1400-1700 (Hull 2000) 255-285.

2 Ruud Lindeman, Yvonne Scherf, Arianne Baggerman and Rudolf Dekker (eds.), Egodocumenten van Nederlanders uit de zestiende tot begin negentiende eeuw: Repertorium (Amsterdam 2016) 11-12, 28 (note 43). 
of life writing and auto/biography research in the Netherlands. International developments - especially in neighbouring European countries - will be taken into account when relevant to the discussion. In order to discuss the state of the art in this field, I will consider four related topics: first, I shall provide an introduction to the field of ego-documents and life writing research with definitions of core concepts; secondly, I will discuss the important lines of research and debates about life writing and auto/biography in the Netherlands, including a reflection on institutional networks and issues of disciplinary demarcation; thirdly, I evaluate the Dutch inventory projects as well as other databases and archives of ego-documents, and propose requirements for future research; and finally, I will review online and printed publications of ego-documents, especially the Egodocumenten series of the Dutch publishing house Verloren that resulted from the inventory projects.

\section{Ego-documents and life writing research: definitions of core concepts}

The term 'ego-documents' was coined by the Dutch historian Jacques Presser in the 1950 as a generic term for diaries, memoirs, personal letters and other forms of autobiographical writing. He eventually defined the term as 'those documents in which an ego intentionally or unintentionally discloses, or hides itself' ${ }^{3}$ Presser was a survivor of the Holocaust and was officially commissioned by the Dutch government to write a history of Dutch Jews during the Nazi regime in the Netherlands. ${ }^{4} \mathrm{He}$ based his findings in large part on interviews and ego-documents ${ }^{5}$, which was rather exceptional for that time. From the nineteenth century onwards - when historians made efforts to define their field as an objective scientific discipline - until well into the twentieth century, most historians were critical of using ego-documents, which they regarded as subjective and unreliable sources. ${ }^{6}$

3 Jacques Presser, “'Clio kijkt door het sleutelgat", in: Maarten Brands, Jan Haak and Philip de Vries (eds.), Uit het werk van dr. J. Presser (Amsterdam 1969) 283-293, 286; Rudolf Dekker, 'Jacques Presser's Heritage: Egodocuments in the Study of History', Memoria y Civilizatión 5 (2002) 13-37, 14; Arianne Baggerman and Rudolf Dekker, 'Jacques Presser, Egodocuments and the Personal Turn in Historiography', European Journal of Life Writing 7 (2018) 90-110, 93. DOI: https://doi.org/10.5463/ejlw.7.263. Presser wrote 'ego-documenten' with a hyphen, which would later disappear. In languages besides Dutch, however, the hyphen is still in use, therefore
I will use the common English spelling 'egodocuments'.

4 Jacques Presser, Ondergang. De vervolging en verdelging van het Nederlandse Jodendom 19401945 (The Hague 1965) https://www.dbnl.org/ tekst/preso03onde01_01/index.php, accessed 14 November 2019. This book was translated into English as Ashes in the Wind: The Destruction of Dutch Jewry (London 1968) and The Destruction of the Dutch Jews (New York 1969).

5 Presser, Ondergang, 521-526.

6 Jeremy Popkin, History, Historians, and Autobiography (Chicago 2005) 11-32; Dekker, 'Jacques Presser's Heritage', 21. 
The disregard for the value of ego-documents changed in the 1980 s when ego-documents became important sources in historical research, due to the rise of history from below, history of mentalities, microhistory and, more generally, the cultural turn in historiography which brought the subjective dimension of history into fashion. ${ }^{7}$ In the Netherlands, research on ego-documents was initiated by historians interested in the workers' movement ${ }^{8}$, women's history ${ }^{9}$ and oral history. ${ }^{10}$ At the history department of Erasmus University in Rotterdam, modelled after the Gesellschaftsgeschichte of the Bielefeld school, the Dutch historian Rudolf Dekker started his pioneering work in the 1980 os on the aforementioned inventory projects of ego-documents. ${ }^{11}$

These inventory projects, funded by the Netherlands Organisation for Scientific Research (first zwo and later by its successor Nwo), were collaborative efforts by scholars from the Erasmus University Rotterdam (Dekker, Baggerman and others) and Valk from the Institute for Dutch History (ING). The aim was to uncover both manuscripts and printed texts of autobiographical writings (such as diaries, autobiographies, memoires and travelogues), from the period 1500-1918, in all Dutch public archives. The results have been made available in several publications, on a website and recently in a book. ${ }^{12}$ These pioneering projects were followed by inventories in other countries, which are, however, more limited in scope than the Dutch inventories with regard to period or genre. ${ }^{13}$

Marijke Huisman, 'Life Writing in the

Netherlands', European Journal of Life Writing 4

(2015) 19-26, 20. DOI: https://doi.org/10.5463/

ejlw.4.171; Claudia Ulbrich, Kaspar von Greyerz

and Lorenz Heiligensetzer, 'Introduction', in: Idem

(eds.), Mapping the 'l': Research on Self-Narratives

in Germany and Switzerland (Leiden 2015) 1; Volker

Depkat, 'Ego-Documents', in: Martina Wagner-

Egelhaaf (ed.), Handbook of Autobiography/

Autofiction (Berlin 2019) 262-267, 263.

8

van het socialisme en de arbeidersbeweging in

Nederland (Biographical Dictionary of Socialism

and the Worker's Movement in the Netherlands),

published in nine volumes between 1986

and 2003. Ger Harmsen, 'De biografie in de

geschiedschrijving van de arbeidersbeweging:

plaats en betekenis', Bulletin Nederlandse

Arbeidersbeweging 19 (1989) 2-31. https://

socialhistory.org/bwsa/harmsen-bna, accessed 14

November 2019.
9 E.g. Mieke Aerts et al., Naar het leven. Feminisme en biografisch onderzoek (Amsterdam 1988).

10 E.g. Selma Leydesdorff, Wij hebben als mens geleefd. Het joodse proletariaat van Amsterdam 1900-1940 (Amsterdam 1987), translated into English as We Lived with Dignity: The Jewish Proletariat of Amsterdam 1900-1940 (Detroit 1998).

11 Huisman, 'Life Writing', 19.

12 The inventories of manuscripts are available via http://www.egodocument.net, accessed 14 November 2019. The first inventory (of egodocuments from the period 1500-1814) has also been published: Lindeman et al., Egodocumenten. The inventory of Dutch ego-documents appearing in print in the period 1813-1914 is available on the website of Huygens ING: http:// resources.huygens.knaw.nl/egodocumenten, accessed 14 November 2019.

13 Today there are inventories of European egodocuments publicly held in Austria, Belgium, 
Simultaneously in the 1980 , after preceding decades in which the 'death of the author' was proclaimed, literary scholars also became more interested in autobiography and 'autofiction', a text that purports to be both fictional and autobiographical. ${ }^{14}$ In the 1990 s life writing emerged as a recognised field in its own right, with its own scholarly journals and conferences. ${ }^{15}$ This research field built on a paradigm shift from the 1970 and 1980 s that led to the reconceptualisation of subjectivity and autobiographical acts. Influential in this respect were post-structural literary theories and feminist, queer, postcolonial, cultural, memory and disability studies. These studies questioned the belief in language's transparency and challenged the traditional concept of the subject, represented in canonical works of autobiography like Rousseau's Confessions (1782), as a coherent, sovereign human being who is capable of self-discovery. Such challenges shattered the cultural authority of the 'master narratives' of the West and led to efforts to widen the hegemonic focus of historiography on the elite of society with more attention for underrepresented and marginalised individuals and groups. ${ }^{16}$ The field of life writing is interdisciplinary in nature and reunites different scholars around the world, albeit with regional differences; whereas for example Anglo-American scholars tend to be based in the field of literary studies, a relatively large number of European life writing scholars are rooted in other disciplines, especially history and the social sciences. ${ }^{17}$

After Presser invented the term 'ego-documents', the word was quickly adopted in Dutch and has also become current in other European languages since the 1990 s. $^{18}$ However, it is remarkable that authoritative

Britain, France, Germany, Italy, Netherlands, Spain, and Switzerland. For an overview of the websites, see: Timothy Ashplant, 'Life Writing "from Below" in Europe: Authors, Archives, Avenues, Arenas', European Journal of Life Writing 7 (2018) 10-48, 38-39. DOI: https://doi.org/10.5463/ ejlw.7.241; Michael Mascuch, Rudolf Dekker and Arianne Baggerman, 'Egodocuments and History: A Short Account of the Longue Durée: Egodocuments and History', Historian 78:1 (2016) 11-56, 55-56. DOI: https://doi.org/10.1111/hisn.12080. Autobiography scholar Philippe Lejeune has made an 'inventory of inventories': 'Inventaire des inventaires de textes autobiographiques', http:// www.autopacte.org/inventaire2.html, accessed 14 November 2019.

Lut Missinne, Oprecht gelogen. Autobiografische romans en autofictie in de Nederlandse literatuur na 1985 (Nijmegen 2013) 17-18; Claudia Gronemann,
'Autofiction', in: Martina Wagner-Egelhaaf (ed.), Handbook of Autobiography/Autofiction (Berlin 2019) 241-246; Popkin, History, Historians, and Autobiography, 24-32. On recent Dutch, literary research on autobiographical writing, autofiction and ego-documents, besides the work of Lut Missinne, see the thematic issue 'Egodocumenten', Vooys 36:4 (2018). Popkin, History, Historians, and Autobiography, 12-13. Smith and Watson, Reading Autobiography, 198199, 204-206.

17 Marijke Huisman, 'Introduction', in: Idem (ed.), Life Writing Matters in Europe (Heidelberg 2012) 9-19, 12.

To give an indication: the bibliographic database Historical Abstracts contains 64 results for the period 1991-2019 (search: 'ego-documents'): English (33), German (17), Dutch/Flemish (5), Spanish (4), French (3), Italian (2). 


\section{B}

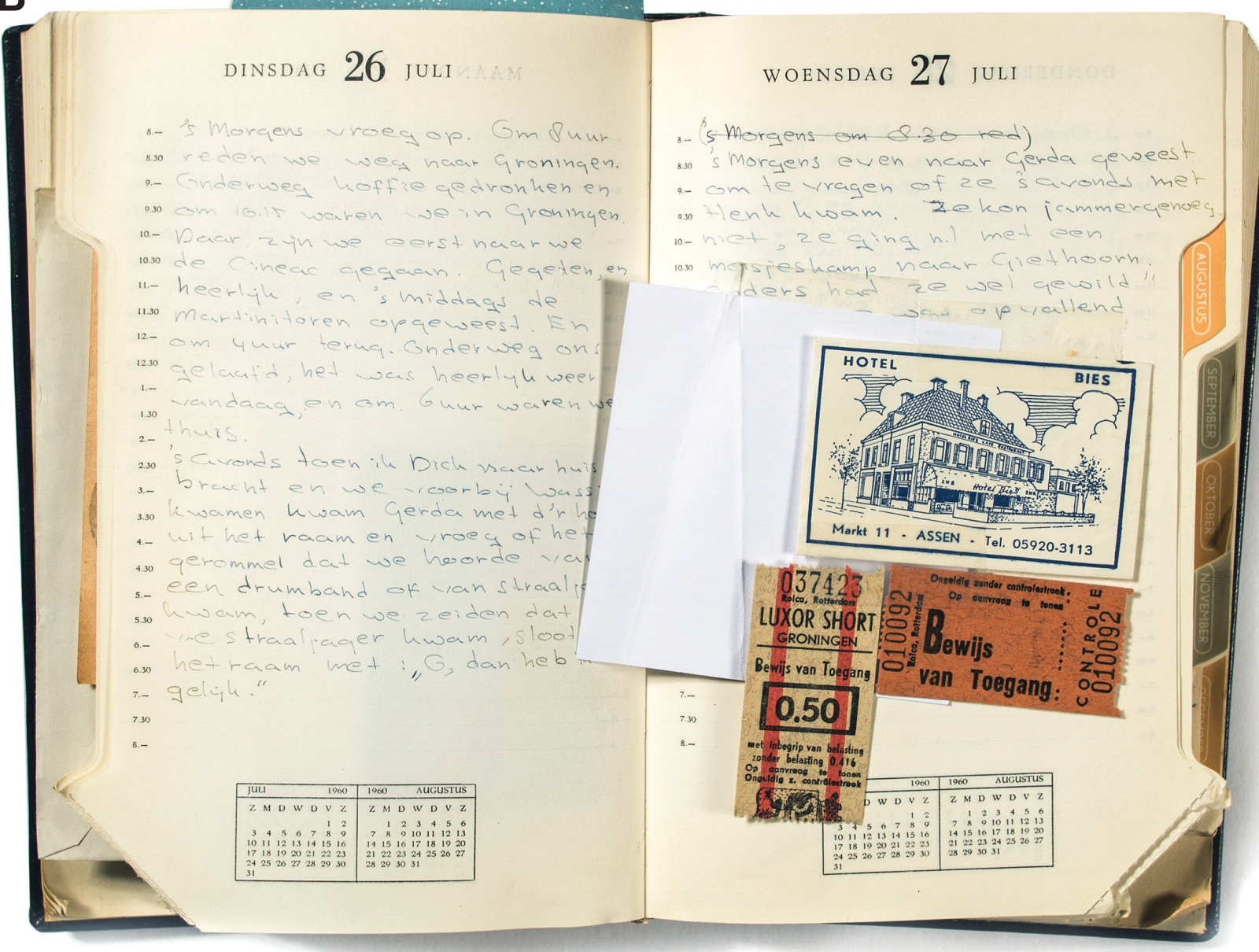

$\Delta$

An example of an ego-document is this diary from the collection of the Nederlands Dagboekarchief (Dutch Diary Archive, Meertens Institute). Diary (anonymous), Collection Nederlands Dagboekarchief (Dutch Diary Archive) (C) Nederlands Dagboekarchief (Dutch Diary Archive) at the Meertens Institute in Amsterdam, and photographer Adrie Mouthaan. 
British and American reference books on autobiography and life writing do not mention the term 'ego-documents'. ${ }^{19}$ Scholarly exchange and discussions on the concept of ego-documents seem to be largely restricted to Dutch, Belgian and German scholars. Besides different national academic contexts, also disciplinary boundaries are at stake. The concept of ego-documents has primarily been used by historians, especially historians of the early modern period. ${ }^{20}$ Literary scholars rather differentiate separate genres, such as letters, diaries, autobiography or autofiction, and are cautious towards the catch-all category of ego-documents, because it 'bears the danger of blinding historians to the formal, narratological, and communicative dynamics of the various forms of self life writing, ${ }^{21}$

The term 'life writing' lumps together even more categories, as it encompasses biographical and autobiographical narratives, whereas 'egodocuments' only refers to autobiographical texts. Life writing can be defined as 'a general term for writing that takes a life, one's own or another's, as its subject'.22 But life writing research also takes into account non-written, even non-verbal sources and 'autobiographical practices' to reconstruct an individual's life. ${ }^{23}$ Many of these 'autobiographical practices' occur when there is no inner drive to express the self, such as applying for a state benefit, making a will or registering a death. ${ }^{24}$ The opening up of concepts such as 'documents', 'writing' and 'authorship' has especially been productive in contexts of colonial or political domination and the reconstruction of the subjectivity and agency of marginalised groups and individuals. ${ }^{25}$

\footnotetext{
Autobiography. The category of 'self life writing'

(p. 4) seems to coincide with the term 'ego-

documents'. In the Encyclopedia of Life Writing

the term 'ego-documents' only shows up in

the entry on the Netherlands and Belgium

(Flanders), as a term between quotation marks.

Sabine Vanacker, 'Netherlands and Belgium

(Flanders)', 647-649. Tellingly, in the recent

Handbook of Autobiography/Autofiction, the

concept of 'ego-documents' has a separate

entry, but this handbook is mainly written by

German scholars. Depkat, 'Ego-Documents',

262-267.

Mary Fulbrook and Ulinka Rublack, 'In Relation:

The "Social Self" and Ego-documents', German

History 28:3 (2010): 263-272, 263, 266, 270 and 272.

DOI: https://doi.org/10.1093/gerhis/ghq065, as

cited by: Depkat, 'Ego-Documents', 262-263.
}

See for example: Smith and Watson, Reading

Depkat, 'Ego-Documents', 264.
22 Smith and Watson, Reading Autobiography, 4.

23 Examples of non-verbal sources that have been used as sources of self-presentation are the pottery of the African American enslaved potterpoet 'Dave the Potter' and the garden of African American writer Alice Walker. Mita Banerjee, 'Life Writing', in: Martina Wagner-Egelhaaf (ed.), Handbook of Autobiography/Autofiction (Berlin 2019) 336-337.

24 'Auto/biographical practices' can be defined as 'the myriad of everyday and frequently fleeting social practices concerned with the articulation of (often competing, sometimes discontinuous) notions of "selves" and "lives". Liz Stanley as cited by Ashplant, "Life Writing "from Below" in Europe: Authors, Archives, Avenues, Arenas', 11, 18-19. Banerjee, 'Life Writing', 336; Ashplant, 'Life Writing "from Below" in Europe: Introduction', 1-9. 


\section{Debates and demarcations}

Criticism has been raised against the seemingly endless multiplicity of materials in life writing research and the methodological problems of studying these different materials under the same framework. A fundamental point of criticism is the blurring of boundaries between biography and autobiography, between history and autobiography and between fact and fiction. ${ }^{26}$ In the Netherlands, discussion of life writing research is rooted in an older debate on biography. In the 1990 soth literary scholars and historians claimed a monopoly on this genre. In 1990 the Werkgroep Biografie (Biography Working Group) was founded, under the umbrella of the Maatschappij der Nederlandse Letterkunde (Society for Dutch Literature, founded in 1766). Some historians, claiming the biography to be a historiographical genre, founded their own Historisch Biografisch Comité (Historical Biographical Committee, 1990). According to the Dutch historian Herman de Liagre Böhl a 'childish struggle' arose between literary scholars, who approached biography as a creative genre, and historians who regarded biography as a scientific genre based on verifiable facts. In fact, this controversy seems somewhat exaggerated, as the Historical Biographical Committee disappeared from the scene very soon. Literary scholars, historians and others have collaborated in the Werkgroep Biografie and its journal Biografie Bulletin (1991). ${ }^{27}$ In 2012, this journal became the Tijdschrift voor Biografie (Journal of Biography), which ended in 2017, but will continue as an annual open access journal called Biographical Studies. ${ }^{28}$

Despite this collaboration, the debate was revived again in the last decade by the Dutch biography scholars Hans Renders and Binne de Haan, respectively professor-director of the Biografie Instituut and his former PhD student. In 2004 the Biografie Instituut (Biographical Institute) was founded as part of the Research Center for Historical Studies at Groningen University. Its mission statement stresses the importance of biography as an academic, historiographical genre. The institute facilitates and supports $\mathrm{PhD}$ projects. So far, twenty $\mathrm{PhD}$-theses were completed, for the greatest Historians, and Autobiography, 15-16; Egelhaaf, 'Introduction: Autobiography/Autofiction Across Disciplines', in: Martina Wagner-Egelhaaf (ed.), Handbook of Autobiography/Autofiction (Berlin 2019) 1-7.

Herman de Liagre Böhl, 'De volledigheidswaan van biografen', BMGN - Low Countries Historical Review 115:2 (2000) 252-260, 252. DOI: http://doi.
org/10.18352/bmgn-Ichr.5219; Huisman, 'Life writing', 20.

28

'Tijdschrift voor biografie gaat digitaal', Biografieportaal, 8 November 2017, https:// biografieportaal.nl/actueel/laatste-nummertijdschrift-biografie/, accessed 14 November 2019. To date, however, the new annual journal has not started yet. 
part biographies. ${ }^{29}$ According to Renders, there is a strong opposition between biography and life writing, summarised as science versus ideology. He makes a plea for a 'critical frontier' between these genres. ${ }^{30}$ Biography is the work of academic historians, based on critical research, respecting the codes of reliability and transparency. Life writers, in contrast, are 'therapists' who want to offer 'retrospective justice' by dedicating an 'overwhelming attention for the deprived in history', such as 'women, coloured people, homosexuals, victims of the Holocaust, and so on'.31 According to Renders, these life writers/therapists 'with backgrounds in Cultural Studies, Gender Studies and Comparative Literature, study individual lives on the basis of autobiographical documents with the ultimate aim to show that the authors of these autobiographical documents were victimized by their social context'. ${ }^{32}$

In a similar vein, De Haan argues that biography is a historiographical genre, because its legitimacy is founded in its claim to truth and in its reference to a past reality. ${ }^{33} \mathrm{He}$ acknowledges that biographers make use of the same autobiographical texts as life writers, but biographers approach these ego-documents as one source among many. The biographer maintains his or her authority by critically judging the value of this personal source material through historical contextualisation and evaluation, whereas the life writer considers texts as 'vehicles for emancipation'. ${ }^{34}$ What is worse, according to De Haan, is the 'eclipse of biography in life writing': biography has been marginalised due to the rise of life writing. He observes that this development is most obvious in the international academic journal Biography (founded in 1978 at the University of Hawaii), which ironically has not been a journal

Groningen, https://www.rug.nl/research/ biografie-instituut/, accessed 14 November 2019; 'De biografie als specialisme', Rijksuniversiteit Groningen, https://www.rug.nl/research/biografieinstituut/specialisme, accessed 14 November 2019. Critical Frontier in Life Writing. Where Biography Shifts into Life Writing', in: Hans Renders and Binne de Haan (eds.), Theoretical Discussions of Biography: Approaches from History, Microhistory, and Life Writing (Leiden 2014) 167-176, 174; Hans Renders, 'Life writing als ideologie', Tijdschrift voor Biografie 1:3 (2012) 78-81.

31 Renders, 'Biography in Academia and the Critical Frontier in Life Writing', 167-176. The term 'retrospective justice' is a quotation from Michael Holroyd, 'Changing Fashions in Biography',
The Guardian, 7 November 2009, http://www. guardian.co.uk/books/2009/nov/07/authormichael-holroyd-review, accessed 14 November 2019.

Renders, 'Biography in Academia and the Critical Frontier in Life Writing', 169. In a similar vein, De Haan considers life writing as 'subjective identity politics'. Binne de Haan, 'The Eclipse of Biography in Life Writing', in: Hans Renders and Binne de Haan (eds.), Theoretical Discussions of Biography: Approaches from History, Microhistory, and Life Writing (Leiden 2014) 177-194, 194. This contribution was also published as a chapter in his Dutch thesis: Binne de Haan, Van kroon tot bastaard. Biografie en het individuele perspectief in de geschiedschrijving (Groningen 2015) chapter 2. De Haan, Van kroon, 23 and 39. De Haan, 'The Eclipse', 178. 
of biography since the 1990 , but of life writing. ${ }^{35}$ De Haan argues that biography 'will have to be careful not to fall prey to Life Writing perspectives in interpreting biographies'. He wants a 'crucial watershed' between biography and life writing and proposes to start a new international journal titled Biography Studies. ${ }^{36}$

The problem is that the charges of Renders and De Haan against life writers are generalisations barely backed up with specific references. ${ }^{37}$ To reject the entire field of life writing by disqualifying it as 'ideological' is a caricature. Firstly, the focus on underexposed individuals and groups in history is not unique to the field of life writing, but resonates with broad concerns about diversity and inclusivity, both inside and outside academia. ${ }^{38}$ In itself, this concern cannot serve as a reason for academic Biography and moderator of the International Auto/Biography Association (IABA) newsletter, plead guilty in a recent volume of Renders and De Haan, in the sense that statistics on both of these mediums back up the claim that 'the study of biography faded into the background and Life Writing came to the foreground'. Craig Howes, 'What are we turning from? Research and Ideology in Biography and Life Writing', in: Hans Renders, Binne de Haan and Jonne Harmsma (eds.), The Biographical Turn. Lives in History (Abingdon 2017) 165-175, 166.

De Haan, 'The Eclipse', 193-194.

Renders refers in very broad terms to 'researchers in Life Writing centres at universities around the world' and 'the Life Writer'. Renders, 'Biography in Academia and the Critical Frontier in Life Writing', 169 and 174. In the lemma on 'Life Writing' in his recent co-authored handbook on biography there are multiple references to fake memoirs or autobiographies, but these sources - which indeed may be unreliable, fictional or ideological - should not be confused with scholarship on these sources. Nigel Hamilton and Hans Renders, The ABC of Modern Biography (Amsterdam 2018) 102-110. Cf. Margit van der Steen, 'Hans Renders en Binne de Haan (eds.), Theoretical Discussions of Biography: Approaches from History, Microhistory, and Life Writing', BMCN - Low Countries Historical
Review 129:1 (2014). DOI: http://doi.org/10.18352/ bmgn-Ichr.9383; Huisman, 'Life Writing in the Netherlands', 22.

Examples in the field of history are the recent conference of KNHG (the Royal Netherlands Historical Society) on 'Exclusion, Silence and Taboo in History' and the theme 'Inclusive History' of the conference 'Historicidagen' (the biennial Dutch Historians' Days), organised by the KNHG in collaboration with the University of Groningen. 'Jaarcongres, 30 november 2018, Haarlem. Uitsluiting, stilte en taboe in de geschiedenis', https://knhg.nl/wp/content/ uploads/2018/07/KNHG-jaarcongres-2018-plan. pdf, accessed 16 February 2020; 'Uitnodiging tot bijdragen. Inclusieve geschiedenis', https:// historicidagen.nl/wp-content/uploads/ sites/437/2018/11/oproep-definitief.pdf, accessed 14 November 2019. Another indication is that the Dutch Minister of Education, Culture and Science Ingrid van Engelshoven has briefed a commission headed by historian James Kennedy to evaluate the Dutch canon and pay more attention to 'the stories and perspectives of different groups in society and the dark sides of history'. 'James Kennedy benoemd tot voorzitter herijking historische Canon van Nederland', 31 May 2019, https://www.rijksoverheid.nl/actueel/ nieuws/2019/05/31/james-kennedy-benoemdtot-voorzitter-herijking-historische-canon-vannederland, accessed 14 November 2019. 
incredibility. Secondly, every historical perspective entails a certain worldview. Consequently, the conception of biography as a historiographical genre has its own ideological assumptions, most importantly that historical events can be explained from the historical actor's perspective. More specifically, Renders and De Haan's quest for historical truth armed with microhistory as a method also has ideological grounds. Historian Marijke Huisman has argued that they seem to use microhistory - which dates back to the 1970 and originated from Marxist ideologies - as an instrument against the implications of postmodernism and the linguistic turn for the historical discipline. ${ }^{39}$ Thirdly, recent discussions on the credibility of several scientific biographies that were published as dissertations, show that the supposed demarcation between 'scientific' biography and 'ideological', hence 'non-scientific' life writing can be disputed. ${ }^{40}$ The latest example in this respect is a biography of Albert Gemmeker, the German commander of the Dutch transit camp Westerbork, written by journalist and television producer Ad van Liempt. The biography was undertaken as a dissertation at the University of Groningen, with historians Doeko Bosscher and Hans Renders as supervisors. ${ }^{41}$ Van Liempt was accused of plagiarism by several critics. ${ }^{42}$ After a complaint of journalist Bart Droog the dissertation was assessed by an integrity committee of the University of Groningen. ${ }^{43}$

Onno Blom's Het litteken van de dood. De biografie van Jan Wolkers (2017), published as a dissertation at Leiden University, led to discussion in the Assessment Committee, after which a new Assessment Committee was formed. This was followed by a debate on the criteria for a scientific biography: Melle Peters, 'Stammenstrijd door biografie over Wolkers', Mare, 16 November 2017, http://www.mareonline.nl/archive/2017/11/16/ stammenstrijd-door-biografie-over-wolkers, accessed 14 November 2019; Thomas de Veen and Gretha Pama, “'Er zijn vele vormen voor een wetenschappelijke biografie"', NRC Handelsblad, 10 November 2017, https://www.nrc.nl/ nieuws/2017/11/10/er-zijn-vele-vormen-voor-eenwetenschappelijke-biografie-13953193-a1580755, accessed 14 November 2019; Marita Mathijsen, 'Dit is waar de wetenschappelijke biografie aan moet voldoen', NRC Handelsblad, 17 November 2017, https://www.nrc.nl/nieuws/2017/11/17/dit-is-waarde-wetenschappelijke-biografie-aan-moet-voldoen14077998-a1581622, accessed 14 November 2019.
41 Ad van Liempt, Gemmeker. Commandant van Kamp Westerbork (Dissertation, Rijksuniversiteit Groningen, 2019).

42 Sander van Walsum, 'Ad van Liempt ligt van verschillende kanten onder vuur. Waar komt de kritiek vandaan?', de Volkskrant, 30 October 2019, https://www.volkskrant.nl/nieuws-achtergrond/ ad-van-liempt-ligt-van-verschillende-

kanten-onder-vuur-waar-komt-de-kritiekvandaan b12794eb/, accessed 14 November 2019; Rudolf Dekker, Plagiaat en nivellering. Nieuwe trends in de Nederlandse geschiedschrijving over de Tweede Wereldoorlog (Amsterdam 2019). Although the integrity committee admitted that the dissertation contained inaccuracies in the acknowledgement of sources, the complaint was rejected as unfounded because 'not all negligence means a violation of scientific integrity'. Thereupon, Bart Droog announced he was appealing the decision at the LowI, the Netherlands Board of Scientific Integrity of the association of Dutch universities (VSNU). 'Proefschrift Van Liempt voldoet aan standaard 
Furthermore, Renders and De Haan's sharp distinction between biography and autobiography is not the current approach in most auto/ biographical research. Instead of a clear-cut distinction, scholars point out 'the multiple and complex entanglements between autobiography and biography'. ${ }^{44}$ The widely used slash between 'auto/biographical' is an indication of this complex relation. ${ }^{45}$ To be sure, autobiography and biography are not interchangeable. ${ }^{46}$ Sources should not be confused with scholarship on these sources. This implies, one could argue, the impossibility of writing an autobiography as a dissertation. But even that assumption can be challenged, for example by the qualitative methodology called 'autoethnography' or by 'ego-histoire', a combination of historical research and autobiography. ${ }^{47}$

The plea of Renders and De Haan for a 'critical frontier' between biography and life writing and between history and literary studies is not productive. Both kinds of researchers make use of autobiographical sources (or texts ${ }^{48}$ ) which should be handled with care; these are complex sources, which require critical analysis in relation to other sources. This source critique gains from insights that life writing studies, gender studies,

van wetenschappelijke integriteit', https://www. rug.nl/news/2019/12/proefschrift-van-liemptvoldoet-aan-standaard-van-wetenschappelijkeintegriteit, accessed 6 January 2020; 'Beroep in plagiaatzaak tegen historicus Ad van Liempt', https://nos.nl/artikel/2317684-beroep-inplagiaatzaak-tegen-historicus-ad-van-liempt.html, accessed 22 January 2020. European-American Reflections', Bulletin of the German Historical Institute 55 (2014) 39-48, https://www.ghi-dc.org/fileadmin/user_upload/ GHI_Washington/Publications/Bulletin55/bu55. zip, accessed 14 November 2019; Smith and Watson, Reading Autobiography, 8-9; Mineke Bosch, 'Experimenten met de biografie: Het congres Rewriting Biography, Groningen, 20 oktober 2016', Tijdschrift voor Biografie 6:1 (2017) 4-14. Auto/Biography Studies; the International Auto/ Biography Association (IABA) and its regional chapters and conferences; and several book titles and publications.
47 The autobiographical plays an important role in a number of academic disciplines, of which 'autoethnography' is exemplary: a hybrid semi-literary and semi-scientific mode of writing, which combines discursive elements of ethnography and autobiography. In the last two decades several dissertations with auto-ethnography as methodology have been published. Smartcat (search engine with collections of university and other libraries worldwide) gives twenty-one results for auto-ethnographies as dissertation. For the definition, see: Christian Moser, 'Autoethnography', in: Martina Wagner-Egelhaaf (ed.). Handbook of Autobiography/Autofiction (Berlin 2019) 232. On 'Ego-Histoire' see the thematic issue on 'History and Autobiography. The Logics of Convergence' of Life Writing 16 (2019).

48 For more information on the ongoing discussions about the relation of reading autobiographies as texts and/or reading them as sources, see Volker Depkat and Wolfram Pyta (eds.), Autobiographie zwischen Text und Geschichts- und Literaturwissenschaft im Gespräch I (Berlin 2017) as cited by: Egelhaaf, 'Introduction: Autobiography/ Autofiction Across Disciplines', 5. 
(post)colonial history and comparative literature have theorised, considering the construction of selves and identities, cultural and narrative conventions, 'silences' in the archives, self-censoring, and so on. This complexity is denied by naive statements such as 'biography, like history is built on fact'. ${ }^{49}$ But how should we understand 'facts'? Which 'facts' do biographers select, from which sources, and how do they interpret them? It is a good tradition - although somewhat neglected in the Netherlands - to publish multiple biographies of a single person. Two recent biographies of Napoleon for example draw fundamentally different conclusions about his historical significance, summarised as 'Napoleon the Great' by Adam Roberts versus 'Napoleon the bungler, the bully, and the unbelievably petty' by Adam Zamoyski. ${ }^{\circ}$ Hence, reality and truth claims about 'facts' as the key building blocks of biographies neglect the complexity of the constructive and narrative character of the historical discipline.

Reviewing the field of auto/biographical research in the Netherlands, the conclusion must be that the academic landscape is much more diverse and complex than portrayed by Renders and De Haan. The study of auto/ biography calls for an interdisciplinary approach, not only between history and literary studies, but also between other disciplines that study autobiographical texts, such as anthropology, philosophy and religious studies. ${ }^{51}$ Moreover, recent developments in the field of digital life narratives and storytelling through digital media, which challenge notions of authenticity and truth, open up entirely new areas of research and interdisciplinary collaboration. ${ }^{52}$ In an interesting project with the telling title 'Ego.Doc', Dutch and other European scholars use different digital methods and computational linguistics to study writing as a coping strategy in times of crisis in Europe. ${ }^{53}$

The origins of life writing studies, as explained above, have indeed led to a strong emphasis on marginalised and often victimised groups and individuals, but this does not mean that other stories are excluded. For instance, in contrast to Renders' conclusion, the life stories of slaveholders, Nazis and collaborators with the apartheid government in South Africa are

Hamilton and Renders, The ABC of Modern

Biography, 108.

'Napoleon the Great? A Debate with Andrew

Roberts, Adam Zamoyski and Jeremy Paxman',

Intelligence Squared, 24 November 2014, https://

www.youtube.com/watch?v=bxQ4TcTcPbl;

Andrew Roberts, Napoleon the Great (London

2014); Adam Zamoyski, Napoleon. The man behind

the myth (London 2018)

51

Egelhaaf, 'Introduction: Autobiography/

Autofiction', 5-6.
52 Innokentij Kreknin, 'Digital Life Narratives/

Digital Selves/Autobiography on the Internet', in: Martina Wagner-Egelhaaf (ed.), Handbook of Autobiography/Autofiction (Berlin 2019) 557-564; forthcoming special issue on 'Storytelling and Identity through Digital Media' of the journal Storytelling, Self, Society.

53 'EGO.DOC - Writing as a Coping Strategy in Times of Crisis in Europe', https://www.c2dh.uni.lu/ projects/egodoc-writing-coping-strategy-timescrisis-europe, accessed 14 November 2019. 
studied as well. ${ }^{54}$ Especially when scholars discuss different perspectives in relation to each other, it can lead to interesting results. Auto/biographical research par excellence can make these different perspectives and their complexities visible. A notable example is the debate on the problematic categories of victims, perpetrators and 'bystanders' or 'implicated subjects'. ${ }^{5}$ An insightful and nuanced volume like German Life Writing in the Twentieth Century (2010), with contributions by both historians and literary scholars helps to understand the mentalities, self-understandings and blind spots, not only of the victims of genocide, but also of those who allowed it to happen. ${ }^{56}$

In the Netherlands, the discussion about victims, perpetrators and 'bystanders' was fuelled by the publication of a book by the Dutch historian Bart van der Boom in 2012.57 Van der Boom's monography led to a fierce debate, first in the newspapers and later in academic journals, and unleashed a Historikerstreit about the role of the Holocaust in the Netherlands. ${ }^{58}$ The aim

\section{Critical Frontier in Life Writing', 169. Some} examples are: Catherine Hall et al., Legacies of British Slave-Ownership: Colonial Slavery and the Formation of Victorian Britain (Cambridge 2014) DOI: https://doi.org/10.1017/CBO9781139626958; Magnus Brechtken, 'Persuasive Illusions of the Self: Albert Speer's Life Writing and Public Discourse about Germany's Nazi Past', in: Birgit Dahlke, Dennis Tate and Roger Woods (eds.), German Life Writing in the Twentieth Century (New York 2010) 71-91; Jacob Dlamini, Askari: A Story of Collaboration and Betrayal in the Anti-Apartheid Struggle (Auckland Park 2014); Barbara Henkes, Negotiating Racial Politics in the Family: Transnational Histories touched by National Socialism and Apartheid (to be published in June 2020 as Volume 11 in the Egodocuments and History Series of Brill).

Christina Morina and Krijn Thijs (eds.), Probing the Limits of Categorization: The Bystander in Holocaust History (New York 2019). A stimulating contribution to trauma theory's victim-perpetrator opposition is the term 'implicated subject', recognising the complexity of subject positions in the field of violence. Michael Rothberg, 'Trauma Theory, Implicated Subjects, and the Question of Israel/Palestine', Profession 2 (2014), https:// profession.mla.org/trauma-theory-implicated- subjects-and-the-question-of-israel-palestine/; Michael Rothberg, The Implicated Subject: Beyond Victims and Perpetrators (Stanford 2019). Mary Fulbrook, 'Life Writing and Writing Lives: Ego Documents in Historical Perspective', in: Birgit Dahlke, Dennis Tate and Roger Woods (eds.), German Life Writing in the Twentieth Century (New York 2010) 25-38, 29. Bart van der Boom, 'Wij weten niets van hun lot'. Gewone Nederlanders en de Holocaust (Amsterdam 2012). For a summary in English, see: Bart van der Boom, 'Ordinary Dutchmen and the Holocaust: A Summary of Findings', in: Bart van der Boom and Peter Romijn (eds.), The Persecution of the Jews in the Netherlands, 1940-1945: New Perspectives (Amsterdam 2012) 29-54. Christina Morina, 'The "Bystander" in Recent Dutch Historiography', German History 32:1 (2014) 101-111. DOI: https://doi.org/10.1093/gerhis/ghtog8; Remco Ensel and Evelien Gans, 'The Dutch Bystander as an Implicated Subject', in: Christina Morina and Krijn Thijs (eds.), Probing the Limits of Categorization. The Bystander in Holocaust History (New York 2019) 107-127. See also the discussion dossier on the value and significance of Chris van der Heijden's book Dat nooit meer [Never Again] (2011) in BMGN - Low Countries Historical Review 128:2 (2013) 71-108. 
of Van der Boom's book was to find out what 'ordinary Dutchmen' knew of the Holocaust. He studied 164 Dutch wartime diaries and found no mention of gas chambers in the diaries, so he concluded that the average Dutch person had no idea of the 'final solution'. Van der Boom has been criticised for his naive, one-dimensional reading of the diaries and for not using other source material to put the diaries in a broader context. ${ }^{59}$ The book was also denounced for fitting into a broader trend in Dutch historiography to 'parallel perpetrators, victims and bystanders', thereby 'levelling' or 'minimizing differences in position, feelings and motives'. ${ }^{60}$

Another example in which different perspectives and experiences have been uncovered and challenged by using ego-documents - among other sources - is the recent, large-scale Dutch research programme 'Independence, Decolonization, Violence and War in Indonesia, 1945-1950', undertaken by the Royal Netherlands Institute of Southeast Asian and Caribbean Studies (KITLV), the Netherlands Institute of Military History (NIMH) and the NIOD, Netherlands Institute for War, Holocaust and Genocide Studies. ${ }^{61}$ While the research project is still ongoing, it has already been criticised from several sides (veterans, victims, and activists) for being one-sided. ${ }^{62}$ Currently, the

Arianne Baggerman and Rudolf Dekker

'Egodocumenten als bron', De Groene

Amsterdammer (24 January 2013) https://

www.groene.nl/artikel/egodocument-als-

bron; Mascuch, Dekker and Baggerman,

'Egodocuments and History: A Short Account

of the Longue Durée: Egodocuments and

History', 40; Morina, 'The "Bystander" in Recent

Dutch Historiography', 104-107. For a more

positive review of the book, see: David Barnouw,

'Nederland was geen deportatieland! - Bart Van

Der Boom, Wij weten niets van hun lot. Gewone

Nederlanders en de Holocaust (Amsterdam 2012)

540 p., €29,90 ISBN 9789461054777 ', Tijdschrift

voor Geschiedenis 126:2 (2013) 287-288. DOI: https://

doi.org/10.5117/TVGESCH2013.2.B25

60

Evelien Gans and Remco Ensel, 'Wij weten iets

van hun lot: Nivellering in de geschiedenis', De

Groene Amsterdammer, 13 December 2012, 32-35,

as cited by Morina, "The "Bystander" in Recent

Dutch Historiography', 104. Cf. Rudolf Dekker,

'Nivellering en vergrijzing', in: Idem, Plagiaat

en nivellering. Nieuwe trends in de Nederlandse

geschiedschrijving over de Tweede Wereldoorlog

(Amsterdam 2019) 77-86.
61 Subproject 'Witnesses and Contemporaries' of the Research Programme 'Independence, Decolonization, Violence and War in Indonesia, 1945-1950', https://www.ind45-50.org/getuigenen-tijdgenoten, accessed 14 November 2019. See also the studies that laid the foundation for this research programme: Rémy Limpach, De brandende kampongs van Generaal Spoor (Amsterdam 2016); Gert Oostindie, Ireen Hoogenboom and Jonathan Verwey, 'The Decolonization War in Indonesia, 1945-1949: War Crimes in Dutch Veterans' Egodocuments', War in History 25:2 (2018) 254-276. DOI: https://doi. org/10.1177/og68344517696525.

62 Hans Moll, 'Het Indië-onderzoek is partijdig', The Post Online, 13 September 2019, https://tpo. $\mathrm{nl} / 2019 / 09 / 13 /$ hans-moll-het-indie\%cc\%88onderzoek-is-partijdig, accessed 3 February 2020. The reaction of NIOD-director Frank van Vree was published on the website of the research project: https://www.ind45-50.org/sites/default/ files/2019-09/Antwoord\%2oFIN\%204.7.2019.pdf, accessed 3 February 2020; Open letter by Jeffry Pondaag and Francisca Pattipilohy (undersigned by 124 people), http://historibersama.com/ 
outcomes of the project cannot be assessed. Whatever the outcome may be, researchers in the project Esther Captain, Eveline Buchheim and Remco Raben emphasise the value of autobiographical sources, such as memoirs, diaries, letters and oral testimonies. Insights from life writing and memory studies, such as the complex relationship between private and public personae, the impact of trauma, and the way people construct their identities in relation to class, gender, race, nation and empire are vital to their research. ${ }^{63}$

It is not surprising that the examples of Dutch debates and research projects above were drawn from the Second World War and the post-war period, as ego-documents have been connected to this period from the beginning. However, research of older ego-documents from the modern, early modern and even medieval periods, also has been thriving since the collaborative efforts of the inventory projects commenced in the mid-1980s. ${ }^{64}$ The inventory projects concentrated on ego-documents from the period of 1500 until 1914, and generated several monographs, text editions and scholarly discussions on a broad variety of topics, such as reading practices, memory, travel, religiosity, political culture, friendship, sexuality, ageing and illness. ${ }^{65}$ These studies have situated the ego-documents in a broader cultural

wp-content/uploads/2017/12/Open-brief-27-

november-2017.pdf; 'Gesprek met ondertekenaars open brief', https://www.ind45-50.org/gesprekmet-ondertekenaars-open-brief, accessed 3 February 2020.

\section{Remembering War Experiences. Memories} About the Second World War in the Dutch East Indies', European Journal of Women's Studies 4:3 (1997) 389-395. DOI: https://doi. org/10.1177/135050689700400309; Harriët Salm, 'Wat heb je nou aan interviews over een oorlog die 75 jaar geleden is geëindigd?', Trouw, 31 August 2019, https://www.trouw.nl/verdieping/wat-hebje-nou-aan-interviews-over-een-oorlog-die-75jaar-geleden-is-geeindigd b7329405/, accessed 14 November 2019; Eveline Buchheim, 'Vrouwen, vrees, verraad: Collaboratie door Nederlandse vrouwen in Nederlands-Indië tijdens de Tweede Wereldoorlog', Leidschrift Historisch Tijdschrift 33:2 (2018); Remco Raben (ed.) Representing the Japanese Occupation of Indonesia. Personal Testimonies and Public Images in Indonesia, Japan, and the Netherlands (Zwolle/Washington 1999); Remco Raben, Wie spreekt voor het koloniale verleden? Een pleidooi voor transkolonialisme (Arnhem 2016).

64 See for example the contributions of the thematic issue 'Egodocumenten' in Vooys 36:4 (2018): Cora van de Poppe, 'Nieuwsberichten als stilistisch voorbeeld voor een vroegmoderne vrouw - Een analyse van het dagboek van Willemken van Wanray (ca. 1573-1647)', 16-26, and Remco Sleiderink, 'In de kast: gebaseerd op ware feiten. Het eigenzinnige oeuvre van Lodewijk van Velthem', 63-67. The following handbook on early modern literary history devotes a separate chapter to ego-documents: Inger Leemans and Gert-Jan Johannes, Worm en donder. Geschiedenis van de Nederlandse literatuur 1700-1800: De Republiek. Geschiedenis van de Nederlandse literatuur Iv (Amsterdam 2013) 485-500. https:// www.dbnl.org/tekst/leem012worm02_01/ leemo12worm02_01_0030.php, accessed 14 November 2019.

65 Herman Roodenburg, 'The Autobiography of Isabella De Moerloose: Sex, Childrearing and Popular Belief in Seventeenth Century Holland', Journal of Social History 18:4 (1985) 517-540. DOI: https://doi.org/10.1353/jsh/18.4.517; Monique 
and social context. Some of these studies focus on a particular ego-document, others concentrate on a wider range of ego-documents. One important example of the latter approach is the Nwo project 'Controlling time', led by Baggerman. She observes a sharp rise in 'impersonal' ego-documents in the nineteenth century, especially pre-printed diaries and calendars in which people record exact times and banal details of everyday life. Inspired by the theories of Reinhart Koselleck, Baggerman explains this exponential growth by a changing sense of time and historical awareness. The sense of individuality - a controversial topic in the field of autobiography for a long time - was not the cause, but instead the product of this autobiographical impulse. ${ }^{66}$

Another line of research on Dutch ego-documents focuses on bodily experiences, emotions and gender. ${ }^{67}$ These studies are related to fundamental

Stavenuiter, Karin Bijsterveld and Saskia Jansens, Lange levens, stille getuigen. Oudere vrouwen in het verleden (Zutphen 1995); Florence Koorn, 'A Life of Pain and Struggle. The Autobiography of Elisabeth Strouven (1600-1661)', in: Magdalene Heuser (ed.), Autobiographien von Frauen: Beiträge zu ihrer Geschichte (Tübingen 1996) 13-23; Luuc Kooijmans, Vriendschap en de kunst van het overleven in de zeventiende en achttiende eeuw (Amsterdam 1997); Judith Pollmann, Religious Choice in the Dutch Republic: The Reformation of Arnoldus Buchelius (1565-1641) (Manchester 1999); Remieg Aerts, Janny de Jong and Henk te Velde, Het persoonlijke is politiek. Egodocumenten en politieke cultuur (Hilversum 2002); Peter Buijs, De eeuw van het geluk. Nederlandse opvattingen over geluk ten tijde van de Verlichting, 1658-1835 (Hilversum 2007); Marijke Huisman, Publieke levens. Autobiografieën op de Nederlandse boekenmarkt 1850-1918 (Zutphen 2008); Arianne Baggerman and Rudolf Dekker, Child of the Enlightenment: Revolutionary Europe Reflected in a Boyhood Diary (Leiden 2009); Jeroen Blaak, Literacy in Everyday Life: Reading and Writing in Early Modern Dutch Diaries. Egodocuments and History Series 2 (Leiden 2009); Lotte van de Pol, 'Research of Egodocuments in the Netherlands. Some Thoughts on Individuality, Gender and Texts', Querelles. Jahrbuch für Frauenund Geschlechterforschung 10 (2005) 233-240; Willemijn Ruberg, Conventional Correspondence:
Epistolary Culture of the Dutch Elite, 1770-1850. Egodocuments and History Series 4 (Leiden 2011); Arianne Baggerman, Rudolf Dekker and Michael Mascuch, Controlling Time and Shaping the Self: Developments in Autobiographical Writing Since the Sixteenth Century (Leiden 2011); Leonieke Vermeer, "“Papa is weder ongesteld": Ziektebeleving in negentiendeeeuwse egodocumenten', De Negentiende Eeuw, 39:3/4 (2015) 230-251, http://demodernetijd.nl/ wp-content/uploads/DNE-2015-34d-Vermeer. pdf, accessed 14 November 2019. On travelogues, see Vibeke Roeper and Diederick Wildeman, Reizen op papier. Journalen en reisverslagen van Nederlandse ontdekkingsreizigers, kooplieden en avonturiers (Amsterdam 1996), publications of Rudolf Dekker, Gerrit Verhoeven, Willemijn Koning, and Anna Geurts, and the thematic issue 'Op reis in de negentiende eeuw', De Negentiende Eeuw 37 (2013) http://demodernetijd.nl/nummers/ DNE-2013-4/, accessed 14 November 2019.

Arianne Baggerman, 'Lost Time. Temporal

Discipline and Historical Awareness in Nineteenth Century Dutch Egodocuments', in: Arianne Baggerman, Rudolf Dekker and Michael Mascuch (eds.), Controlling Time and Shaping the Self. Developments in Autobiographical Writing Since the Sixteenth Century (Leiden 2011) 455-477, 467.

67 Willemijn Ruberg, 'The Letter as Medicine: Studying Health and IIIness in Dutch Daily 
methodological developments in the field of ego-documents, in which life narratives are not merely regarded as representations but as 'performative' sources in themselves: what did a text do to both its author and its recipients, and what function did it have ${ }^{68}$ In this respect, the cultural historian Willemijn Ruberg has analysed Dutch correspondence practices in the late eighteenth and the early nineteenth centuries in relation to cultural conventions and ideas about health, illness, sexuality and death. ${ }^{69}$ Another quite specific example of life narratives as performative sources is the way diaries in the eighteenth and nineteenth centuries functioned as mediums used to register and control masturbation, and they also reveal ways in which the dominant medical discourse against this life-threatening 'secret vice' was changed or resisted. ${ }^{70}$ This self-disciplining aspect of keeping a diary can be seen as a historical precursor of present-day mobile apps and wearable technologies that allow individuals to track their daily steps, caloric burn, heart rate, sleep, menstruation, fertility and, indeed, their masturbation habits. $^{71}$

Dutch research on ego-documents has also paid particular attention to children and adolescents. ${ }^{72}$ The diary of Otto van Eck (1791-1797) is the

Correspondence, 1770-1850', Social History

of Medicine 23:3 (2010) 492-508, 498. DOI: https://doi.org/10.1093/shm/hkq012; Leonieke Vermeer, “'Cheerful Angels Looking Down on Us": Parental Emotions in Diaries about the Illness and Death of Infants and Young Children (1780-1880)', European Journal of Life Writing 7 (2018) 133-150. DOI: https://doi. org/10.5463/ejlw.7.265. This line of research also thrives in Belgium: Laura Nys, Liefde, Lijden en Verzet. Emotionele (tegen)praktijken in het Rijksopvoedingsgesticht voor lastige of weerspannige meisjes te Brugge (1927-1941) (Master's thesis in history: Ghent University 2014) https://lib. ugent.be/fulltxt/RUG01/002/162/481/RUGo1002162481_2014_0001_AC.pdf; Nys is currently writing a PhD on 'Mixed feelings. Emotion, gender and discipline in ego-documents of youth offenders (1890-1965)', funded by FWO (Flanders Research Foundation). See also several early modern history projects at the KU Leuven on emotions and sensory experiences in which ego-documents are used as important source material: https://www.arts.kuleuven.be/ nieuwetijd/onderzoek/emotiegeschiedenis.
68 Ruberg, 'The Letter', 498. For an overview of the performative turn in history, see Peter Burke, 'Performing History: The Importance of Occasions', Rethinking History 9 (2005) 35-52. DOI: https://doi.org/10.1080/1364252042000329241.

69 Ruberg, Conventional Correspondence; Ruberg, 'The Letter'.

70 Leonieke Vermeer, 'Tiny Symbols Tell Big Stories. Naming and Concealing Masturbation in Diaries (1660-1940)', European Journal of Life Writing 6 (2017) 101-134. DOI: https://doi.org/10.5463/ ejlw.6.209.

71 Vermeer, 'Tiny Symbols Tell Big Stories', 125; Leonieke Vermeer, 'The Quantified Self in Diaries (1780-1940)', IABA Europe Conference, 20 June 2019, Madrid; Fenneke Sysling, 'Measurement, Self-Tracking and the History of Science: An Introduction', History of Science (2019) 5. DOI: https://doi.org/10.1177/0073275319865830; 'Call for Papers: Life Writing in the Digital Age: Quantification, Optimization and the Self', http:// quantified-self.org/life-writing-in-the-digital-age, accessed 29 January 2020.

72 Rudolf Dekker, Childhood, Memory and Autobiography in Holland: From the Golden Age 
first comprehensive diary by a child found in Europe to date. ${ }^{73}$ In addition, Alexander van Goltstein's diary (180o-1808) is one of the first written by an adolescent and an early example of a journal intime - a diary as an instrument of self-knowledge and an outlet for emotions. ${ }^{74}$ Moreover, childhood memories recounted in autobiographies are also used as a rich, albeit complicated historical source. ${ }^{75}$ The most famous Dutch ego-document by a child - or rather adolescent - is, of course, the diary of Anne Frank, which has recently been republished as part of her 'collected works', including the different versions of the diary. ${ }^{76}$ Furthermore, Dutch autobiographies of childhood published in the 1990 s have been interpreted as a challenge to the Romantic conception of childhood (a combination of natural goodness, innocence and creativity). ${ }^{77}$

to Romanticism (Amsterdam 2000); Mineke van Essen, 'Tussen biografisch dagboek en Bildungsroman. Hoe echt is de jongen Jaap Kann?', Biografie Bulletin 8 (1998) 79-86; Monica Soeting, Nina Wijsbek and Rob van Essen, De puberdagboeken. Hoe tieners over hun leven schrijven (Amsterdam 2017).

Arianne Baggerman and Rudolf Dekker (eds.), Otto van Eck, Dagboek 1791-1797. Egodocumenten 12 (Hilversum 1998); Arianne Baggerman and Rudolf Dekker, 'The Social World of a Dutch Boy: The Diary of Otto van Eck (1791-1796)', in: Susan Broomhall (ed.), Emotions in the Household, 12001900 (London 2008) 252-268. DoI: https://doi. org/10.1057/9780230286092. Jurgen Limonard (ed.), De vertrouwde van mijn hart. Het dagboek van Alexander van Goltstein (1801-1808). Egodocumenten 4 (Hilversum 1994); Dekker, Childhood, Memory and Autobiography in Holland, 50-58; Leonieke Vermeer, '1800. Een zeer intiem adolescentendagboek', in: Lex Heerma van Voss et al. (eds.), Wereldgeschiedenis van Nederland (Amsterdam 2018) 361-366. On journal intime, see Philippe Lejeune, Aux Origines du Journal Personnel: France, 1750-1815 (Paris 2016).

Hugo Röling, Zichzelf te zien leven. Herinneringen aan Nederlands en Vlaams gezinsleven 1800 - 1970 (Amsterdam 2006); Hugo Röling, 'The Experience of Sex Education in the Netherlands and Flanders in Childhood Memories from the First Half of the Twentieth Century', in: Lutz Sauerteig and
Roger Davidson (eds.), Shaping Sexual Knowledge: A Cultural History of Sex Education in Twentieth Century Europe (New York 2009) 236-250.

Anne Frank, Verzameld Werk, eds. Mirjam Pressler, Gerhard Hirschfeld and Francine Prose (Amsterdam 2013). On the complicated genesis of the text and its edition history, see also: David Barnouw and Gerrold van der Stroom (eds.), The Diary of Anne Frank: Critical Edition (New York 1989), rev. ed. The Diary of Anne Frank: The Revised Critical Edition (New York 2003); Philippe Lejeune, 'How Anne Frank Rewrote the Diary of Anne Frank', in: Idem, On Diary (Honolulu 2017) 237-266. In 2019 a new edition of the diary, under the title Dear Kitty or Liebe Kitty, was published only in Germany, Austria and Switzerland due to copyright laws. On the battle between publishers and the Anne Frank Fonds, a Swiss foundation that owns the copyright to the diaries, see: 'Anne Frank Publishers Locked in Copyright Battle', The Telegraph, 17 November 2015, https://www. telegraph.co.uk/news/worldnews/europe/ netherlands/12001720/Anne-Frank-publisherslocked-in-copyright-battle.html, accessed 3 February 2020. Helma van Lierop, 'How the Reader Matters. Autobiographies of Childhood for Young Readers', European Journal of Life Writing 7 (2018) 1-16. DoI: https://doi.org/10.5463/ejlw.7.246; 'Conference Beyond Boundaries: Authorship and Readership in Life Writing', https://www. 
The debates mentioned above, as well as the research projects and publications, demonstrate that the field of ego-documents and life writing research in the Netherlands is very productive and exposes a variety of perspectives and experiences. The biography as well is flourishing, also as an academic genre, notwithstanding discussion on some biographies published as dissertations. Several biographers experiment with new approaches, such as abandoning the linear, chronological form for a more dynamic storyline. ${ }^{78}$ Furthermore, auto/biographical texts play a major role in public and academic debates, especially on the war and post-war period. Several examples show that auto/biographical research is also benefitting from an interdisciplinary approach, including gender studies, memory studies, history of emotions, body history, and collaboration between historians, literary scholars and others.

In fact, as pointed out above, collaboration is what occurred in the decades after the 'childish struggle' in the early 1990s. Although there is no Dutch equivalent of the many research centres on life writing ${ }^{79}$, there are several platforms in which Dutch auto/biography scholars of various disciplines collaborate. On a national level, I have already mentioned the Werkgroep Biografie and its journal. Other significant examples are the working group on biography and autobiography at the Huizinga Institute (since 1999$)^{80}$ and the Biography Portal of the Netherlands. ${ }^{81}$ On an international level, scholars are working together at the International Auto/Biography Association conferences (since 1999), in the European Journal of Life Writing (since 2012) and in the interdisciplinary expert group 'Unhinging the National Framework: Platform for the Study of Life-Writing and Transnationalism' led by Babs Boter (vU Amsterdam) since $2016 .^{82}$

tilburguniversity.edu/nl/over/schools/tshd/ departementen/dcu/event/beyond-boundaries, accessed 14 November 2019.

Bosch, ‘Experimenten met de biografie'; Maaike Meijer, 'De biograaf laat zich zien', Trouw, 27 October 2018. https://www.trouw.nl/cultuurmedia/de-biograaf-laat-zich-zien b3936gef/, accessed 14 November 2019.

E.g. Centre for Life-Writing Research, King's College London; The Oxford Centre for LifeWriting (OCLW), Wolfson College, University of Oxford; Centre for Life History \& Life Writing Research, University of Sussex; Autobiography. Forum for Life Writing Research, Universität Münster; Mainz Center for Life Writing, Johannes Gutenberg Universität Mainz.
80 'Projectgroep (Auto)biografie/Egodocumenten', Huizinga Instituut, https://www.huizingainstituut. $\mathrm{nl} /$ projectgroep-autobiografie/, accessed 14 November 2019.

81 'Biography Portal of the Netherlands', Biografisch Portaal, http://www.biografischportaal.nl/en, accessed 14 November 2019.

82 IABA organises international conferences since 1999 (biannually since 2008) in Asia, North America, Australia and Europe. IABA Europe was founded as the first of the regional branches in 2009, when the founding conference 'Life Writing in Europe' was held at vu University in Amsterdam. https://sites.google.com/a/ualberta. ca/iaba/conferences; https://sites.google.com/a/ ualberta.ca/iaba/home/about-iaba, accessed 14 November 2019; 'Unhinging the National 
These developments point towards the increasing importance of national and international networks of auto/biography scholars from several disciplinary backgrounds. The next section discusses the opening up of egodocuments, and the challenges and opportunities associated with digitisation, which also undeniably calls for more rather than less collaboration.

\section{The inventory projects and beyond: online databases of ego-documents in public, private and community archives}

The main Dutch database of ego-documents, http://www.egodocument. net/, is a result of the large inventory projects which have been undertaken since the mid-1980s. The inventory projects have proven to be very valuable. They have brought to light previously unknown texts that became part of monographs and scholarly discussions, such as the autobiography of Hermanus Verbeeck and the diary of David Beck, both from the seventeenth century. Some of the ego-documents found are very significant in an international context, such as the diary of Magdalena van Schinne (17861805), considered to be one of the earliest examples of a journal intime. Other remarkable examples have already been mentioned, such as the diaries of Otto van Eck and Alexander van Goltstein.

Undoubtedly, many researchers - including myself - have gratefully made use of the database. Unfortunately, there are also some downsides. Firstly, the databases of manuscripts (1500-1814 and $1814-1914)^{83}$ are not searchable by keyword. It is telling that Dekker calls it a 'list', because it is indeed more akin to a list than to a searchable database. ${ }^{84}$ Partly as a result of the lack of a search engine, it is difficult to know precisely how many egodocuments the manuscript database contains. ${ }^{85} \mathrm{It}$ is also unclear whether

Framework: Platform for the Study of Life-

Writing and Transnationalism', https://clue.vu.nl/ en/projects/Unhinging-the-National-Framework/ index.aspx, accessed 14 November 2019. See also the interdisciplinary volume: Marijke Huisman, Life Writing Matters in Europe (Heidelberg 2012). egodocument.net/egodocumententot1814.html and 'Egodocumenten 1814-1914 (repertorium)', http://www.egodocument.net/repertorium.html, accessed 14 November 2019.

84 Rudolf Dekker, 'Voorwoord', http://www. egodocument.net/egodocumententot1814.html. In contrast to the databases of manuscripts, the database of printed egodocuments (1813-1914), hosted by Huygens ING, is searchable by keyword.

'Repertorium van egodocumenten van NoordNederlanders uit de negentiende eeuw', http:// resources.huygens.knaw.nl/egodocumenten, accessed 14 November 2019. In international perspective this is exceptional, as most inventories in other countries are not searchable by keyword.

85 According to the website, the database 'Egodocuments until 1814' contains 'approximately 1200 texts'. This is specified in the recent book publication as precisely 1121 egodocuments. Lindeman et al., Egodocumenten, 11. For the database 'Egodocumenten 1814-1914' no number can be found on the website. In print, 
any additions have been made. As explained on the website, the list is a 'preliminary result of the inventorisation', which is not yet complete and will thus continue to grow. ${ }^{86}$ Dekker has explained that he keeps track of additions, but that these are not yet entered into the website. ${ }^{87}$ An update of the website is planned, but that will take time, effort and money. It is Dekker's deliberate choice to manage the website himself - and to publish the inventories in book form - because websites managed by universities are more at risk of ending up in the 'virtual garbage can'. ${ }^{88}$ The website with the inventory of printed ego-documents (1813-1914), hosted by Huygens ING, states that their aim is to integrate the different inventories (both manuscripts and printed ego-documents) and make them accessible, but this combined web portal has not yet been established. ${ }^{89}$

Secondly, an important lacuna in the inventories and the databases are ego-documents in private archives. Sources outside public archives such as conversion narratives kept by religious organisations or writings of patients in mental asylums - are especially important for life writing 'from below'. ${ }^{90}$ The Centraal Register Particuliere Archieven (Central Register Private Archives, CRPA) in the National Archives in The Hague contains approximately 5000 private archives from the period 1965-1996. Unfortunately, this register has not been updated since $1998 .{ }^{91}$ Since 2007, there have been several pleas by heritage and archival committees that it is the responsibility of the government to safeguard private archives as cultural heritage. The National Archives should take the lead in this and could learn from the British example, the National Register of

Arianne Baggerman mentions that 'more than 3833 diaries and autobiographies were written

by Dutch people born before 1900' of which 316 were written before 1800 . Arianne Baggerman, 'Lost Time', 462. net/egodocumententot1814.html, accessed 14 November 2019.

Dekker, 6 December 2018. The additions are, however, mentioned in the book edition of 2016 : Lindeman et al, Egodocumenten.

Dekker, 6 December 2018. Dekker mentioned as an example the website that Hugo Röling had made of family memories ('Herinneringen aan Nederlands en Vlaams gezinsleven 17701970'), hosted by the University of Amsterdam, which does not exist anymore. The results of this research project can be found in: Röling, Zichzelf te zien leven. On the potential dangers of digital initiatives, see also: Mascuch, Dekker and Baggerman, 'Egodocuments and History', 56.

89 'Repertorium van egodocumenten van NoordNederlanders uit de negentiende eeuw', http:// resources.huygens.knaw.nl/egodocumenten, accessed 14 November 2020.

90 Ashplant, 'Life writing "from Below" in Europe: Authors, Archives, Avenues, Arenas', 17.

91 The Nationaal Archief Den Haag, Centraal Register Particuliere Archieven (CRPA), inv. 430. https://www.nationaalarchief.nl/onderzoeken/ archief/2.14.26, accessed 14 November 2019; Nouk Ruitenberg, Mieke van Leeuwen-Canneman and Francine Hartman, 'Het Centraal Register van Particuliere Archieven (CRPA)', Archievenblad, 10 December 2009 . 
Archives. ${ }^{92}$ To date, there is no Dutch equivalent, although there is growing awareness of the importance of private archives. ${ }^{93}$

However, these efforts do not necessarily depend on government initiatives 'from above', as so-called 'community archives' show. These community archives are defined by information specialist Andrew Flinn as 'the grassroots activities of documenting, recording and exploring community heritage in which community participation, control and ownership of the project is essential' ${ }^{94}$ Since 1984, several European diary archives have been established, which can be considered specific genre-based types of community archives. ${ }^{95}$ The Dutch Diary Archive (NDA) was founded in 2009 by Mirjam Nieboer and Monica Soeting. In 2014, the collection of the NDA was transferred to the Meertens Institute in Amsterdam. The NDA took the initiative to found a network of European Diary Archives and Collections (EDAC) in 2015, which currently has eleven member institutions. ${ }^{96}$ The collection consists of private donations and contains approximately 1350 ego-documents (100o diaries, 350 letters) and is still growing. ${ }^{97}$ As a community archive, the word 'diary' is defined in a very broad sense, with regard to content as well as material

Margreet Windhorst, Gewaardeerd verleden.

Bouwstenen voor een nieuwe waarderingsmethodiek voor archieven (2007) 50, https://openaccess. leidenuniv.nl/bitstream/handle/1887/15559/ gewaardeerd+verleden.pdf?sequence $=2$, accessed 14 November 2019. The British register contains information about the nature and location of archival collections in the UK and overseas and has a Historical Manuscripts Commission, relating specifically to historical manuscripts in private archives. http:// discovery.nationalarchives.gov.uk/; http://www. nationalarchives.gov.uk/about/our-role/advisorycouncil/forum-on-historical-manuscripts-andacademic-research/.

Kennisplatform Particuliere Archieven, https://kia. pleio.nl/groups/view/41453152/kennisplatformparticuliere-archieven, accessed 14 November 2019; 'Landelijke samenwerking in het project Particuliere archieven op de kaart', https://kia. pleio.nl/groups/view/41453152/kennisplatformparticuliere-archieven/wiki/view/46300342/ landelijke-samenwerking-in-het-projectparticuliere-archieven-op-de-kaart, accessed
14 November 2019, and 'Platform Particuliere

Archieven', http://www.familiearchieven.nl/ platformparticulierearchieven.html, accessed 14 November 2019; Archiveren is vooruitzien. Visie van BRAIN en KVAN op de koers en de inrichting van het archiefwezen (2009) 14.

Community Archives: Some Opportunities and

Challenges', Journal of the Society of Archivists 28:2 (2007) 151-176, 153. DOI: https://doi. org/10.1080/00379810701611936.

The Italian Archivio Diaristico Nazionale (1984) was the first diary archive. Marijke Huisman, 'Monuments for the Common (Wo)man: Diary Archives in Europe. Interview with Monica Soeting, co-founder of the Dutch Diary Archive', Tijdschrift voor Genderstudies 19:3 (2016) 373-387. DOI: https://doi.org/10.5117/ TVGN2016.3.HUIS.

96 'European Ego-Documents Archives and Collections Network - EDAC', http://www.edac-eu.eu/?p=346, accessed 14 November 2019. 'Nederlands Dagboekarchief', https://www. dagboekarchief.nl, accessed 14 November 2019. 
form. ${ }^{98}$ A group of volunteers reads and indexes the documents to make them accessible. ${ }^{99}$ In the project 'Data from Diaries' (2016), financed by DANs (Data Archiving and Networked Services), the metadata of the collection has been made digitally accessible to researchers, although the database is only available under 'restricted access' due to privacy-sensitive information. ${ }^{100}$ Remarkable examples from the NDA collection are published in a series. ${ }^{101}$

In general, it can be concluded that the important shift promulgated in the field of life writing towards a widening of hegemonic historiography is not yet clearly visible in the databases of Dutch ego-documents. The databases from the inventory projects demonstrate several imbalances: the authors are far more often men than women (the share of the latter is at most 10 percent for the period 1500-1814); they primarily belong to middle and higher classes; and they often lived in the urban, western parts of the Netherlands (Holland and Zeeland). ${ }^{102}$ These imbalances are obviously inherent to this type of source material, but greater efforts could be made to 'stretch the archive' beyond its traditional limitations. For example, Icelandic research has shown that many ego-documents by women have entered in the archives unascribed, or under the names of their fathers or husbands. ${ }^{103}$ Life writing studies reveal creative

for inclusion. A diary collection may contain one or several diaries, notes, scrapbooks, medical records, as well as photo albums. Even objects, like the suitcases or satchels in which these documents were kept, are considered valuable, but the Meertens Institute which houses and owns the collection, has strict rules against storing objects. Huisman, 'Monuments', 381383.

\section{Dagboekarchief uitgroeide tot een verzameling} vol levensverhalen', 10 June 2019, https://www. parool.nl/nederland/hoe-het-nederlandsdagboekarchief-uitgroeide-tot-een-verzamelingvol-levensverhalen b24b2668/, accessed 14 November 2019.

100 Douwe Zeldenrust, Nina Wijsbek and Menzo Windhouwer, 'Data van Dagboeken (Data from Diaries)', Research Data Journal for the Humanities and Social Sciences 1:1 (2016) 41-47. DOI: https:// doi.org/10.1163/24523666-01000008; 'KDP Data van dagboeken', https://easy.dans.knaw.nl/ui/ datasets/id/easy-dataset:67515, accessed 14 November 2019.
101 'Publicaties van het Nederlands Dagboekarchief', https://www.dagboekarchief.nl/publicatiereeks/, accessed 14 November 2019.

102 Lindeman, Scherf and Dekker, Egodocumenten van Nederlanders uit de zestiende tot begin negentiende eeuw, 12-22. These numbers and conclusions refer to the inventory of manuscripts from the period $1500-$ 1814. But they probably can be extrapolated to the inventory of printed ego-documents (1813-1914), at least for the proportion of women: 508 (10 percent) of the 5033 ego-documents have been written by women. 'Repertorium van egodocumenten van Noord-Nederlanders uit de negentiende eeuw', search option 'geslacht' (sex). Within the category of printed autobiographies the share of female writers is slightly higher (17 percent between 18501910). Marijke Huisman, 'Selves in Numbers: A Book-Historical Perspective on Nineteenth-Century Autobiography in the Netherlands', Lifewriting Annual. Biographical and Autobiographical Studies 4 (2015) 203-221, 205. https://marijkehuisman.com/ pdf/huisman-from-lifewriting_4_Book_2_5_2016-2. pdf, accessed 14 November 2019.

103 Alexis Wolf, 'Introduction: Reading Silence in the Long Nineteenth-Century Women's Life 
and critical ways to engage with a wide range of sources, both incorporated within and peripheral to traditional institutional archives. Fortunately, there are some promising recent developments in this direction, such as the above mentioned Dutch and other European diary archives. The Black Archives in Amsterdam is another important example of a recently established community archive. $^{104}$

Moreover, since the funding for the inventory projects has ended in 1996, the continuation and extension of the databases, as well as improvements, such as the implementation of a user-friendly search interface, are not guaranteed. It would be logical and very relevant to establish inventories of ego-documents from the twentieth century in a follow-up project. Furthermore, as argued above, ego-documents in private and community archives should also be incorporated.

A combined web portal with a user-friendly search interface, which brings together all the Dutch ego-documents - both printed texts and in manuscript form - in public, private and community archives, would be the ultimate desideratum for researchers in this field as well as for the wider public. This web portal could also be integrated into international research infrastructures such as Europeana and CLARIN. ${ }^{105}$ In addition to the inventories on http://www.egodocument.net/, I consider two possible starting points for this combined web portal: firstly, the Biography Portal of the Netherlands, an online collection of biographical information on notable figures in Dutch history, which already refers to many ego-documents; ${ }^{106}$ and secondly, www.archieven.nl, on which the collections of Dutch archives are searchable and publicly accessible. Approximately 80 percent of all the archival services in the Netherlands cooperate on www.archieven.nl. ${ }^{107}$ This database mainly contains public archives, but also several private archives. ${ }^{108}$

Writing Archive', Interdisciplinary Studies in the Long Nineteenth Century 27 (2018) 1-10, 6. DOI: https://doi.org/10.16995/ntn.841; Sigurður Gylfi Magnússon, 'Gender: A Useful Category in the Analysis of Ego-Documents?', Scandinavian Journal of History 38:2 (2013) 202-222. DOI: https:// doi.org/10.1080/03468755.2013.774291.

$104 \mathrm{http}: / /$ www.theblackarchives.nl/, accessed 14 November 2019.

105 Europeana provides access to digitised collections of European archives, libraries and museums: https://www.europeana.eu/portal/en, accessed 14 November 2019. CLARIN (European Research Infrastructure for Language Resources and Technology) already contains a collection of Dutch letters: the collection 'Brieven als buit'
(Letters as Loot): 'Historical corpora', https:// www.clarin.eu/resource-families/historicalcorpora, accessed 14 November 2019. According to Zeldenrust et al. (see note 100) the 'Data in Dagboeken' project should also be available via CLARIN, but this is not the case yet.

106 The website 'Biography Portal of the Netherlands' exists since 2010. http://www.biografischportaal. nl/en; accessed 14 November 2019; https:// nl.wikipedia.org/wiki/Biografisch_Portaal, accessed 14 November 2019.

107 The website www.archieven.nl exists since 2002. https://www.archieven.nl/nl/, accessed 14 November 2019.

$108 \mathrm{~A}$ large public archive not involved is the Stadsarchief of Amsterdam (Amsterdam City 
Unfortunately, searching for ego-documents via the website of www. archieven.nl does not yet function effectively. The website is searchable by keyword, but the search term 'egodocument' only gives a fraction of the results one would expect, compared to the inventories of ego-documents. ${ }^{109}$ Apparently, most archives do not use this term as a specific designation. This is understandable, as the general category of 'ego-documents' may appeal to historians, but is not suitable for archivists. Nevertheless, the more specific term 'dagboek' (diary) does not function well either. ${ }^{110}$

Thus, the search options should be improved and the scope of archival services could be expanded, but there are, nevertheless, three major advantages of www.archieven.nl in comparison to the above mentioned databases of ego-documents: firstly, there is a search engine; secondly, it is dynamic, therefore additions will be visible; and thirdly, some manuscripts are digitally accessible, above all the entire collection of diaries and other egodocuments belonging to the NIOD. ${ }^{111}$ Ideally, a central 'dataportal' with all egodocuments in www.archieven.nl could be created, similar to the one that has been developed for charters created and hosted by Huygens ING. ${ }^{112}$

Archives). Furthermore, a private archive like ATRIA (Institute on gender equality and women's history), which contains a lot of ego-documents, and community archives, such as the earlier mentioned Dutch Diary Archive and the Black Archives, is not included yet.

109 For example, a search in www.archieven.nl leads to the conclusion that the collection 'Egodocumenten' of the Gelders Archief only contains sixteen 'Alba Amicorum'. Although this type of source can be classified as egodocument, it is not the most typical sort and there are several other ego-documents in the collection of the Gelders Archief which are not classified as such. https://www.archieven.nl/nl/ zoeken?mivast $=0 \&$ mizig $=83 \&$ miadt $=$ 37\&milang=nl\&mizk_alle=egodocumenten\& miview=ldt, accessed 14 November 2019. On 'Album Amicorum' as ego-document, see: 'Album amicorum', in: Gerrit Jan van Bork et al., Algemeen letterkundig lexicon, https://www.dbnl.org/tekst/ dela012alge01_01/dela012alge01_01_00126.php, accessed 14 November 2019.

The search term 'dagboek' (search the entire database - filter on Materiaal - Archieftoegang) leads to an enormous amount of results, but these are only partly journals in the sense of ego-documents by individuals; they also contain reports of governmental bodies, companies, et cetera. https://www.archieven.nl/nl/zoeken? mivast $=0 \&$ mizig $=0 \&$ miadt $=0 \& m i q=1 \&$ milang $=$ nl\&misort=score\%7Cdesc\&mizk_alle= dagboek\&mif3=4\&miview=Ist, accessed 14 November 2019. Dagboeken-NIOD (Instituut voor Oorlogs-, Holocaust- en Genocidestudies), https://www. archieven.nl/nl/zoeken?miadt=298\&mizig=18, accessed 14 November 2019. A selection of these ego-documents is also available as collection of 'war diaries': 'Oorlogsdagboeken', http:// www.geheugenvannederland.nl/nl/geheugen/ pages/collectie/Oorlogsdagboeken, accessed 14 November 2019. Obviously, a researcher interested in ego-documents related to war can also visit the NIOD website directly, but the advantages of an integrated web-portal are evident. Many historical studies cover numerous ego-documents not limited to one archive.

Furthermore, several ego-documents related to war are not in the collection of the NIOD, but in other archives. Digitale Charterbank Nederland, https:// charterbank.huygens.knaw.nl/, accessed 14 November 2019. 
Most of the ego-documents in the above mentioned archives and databases have not been digitised or published, so for the majority of sources a visit to the archive is necessary. ${ }^{113}$ As the NIOD collection shows, ego-documents connected to the Second World War and the Holocaust are a priority in digitisation projects. The reasons for this could be the general dominance of this topic in Dutch historiography and the fact that the study of egodocuments in the Netherlands in the 1950 s was linked to the Second World War from the beginning. Fortunately, in addition to the NIOD, other research institutes and archives, such as Huygens ING, ATRIA and regional and city archives, have also digitised some ego-documents. ${ }^{114}$ Specific foundations may stimulate digitisation, such as the Stichting Réveil-Archief which, with the aid of other partners and funding bodies, made the extensive diary of Willem de Clercq, poet and leader of the Protestant Réveil movement, available in online form. ${ }^{115}$ Subsequently, private initiatives and growing public interest in genealogy and family history have also led to digital editions of egodocuments. ${ }^{116}$

The advantage of online publication of ego-documents, in relation to the printed editions that will be discussed below, is that the visual and material aspects of the ego-document come to the fore better and that the websites often include search options. ${ }^{117}$ The best examples encompass

es Jeurgens estimated in 2013 that only about 2 percent of the analogue material housed in Dutch archival institutions was available digitally, although he also mentioned the sustained effort of archives to make 10 percent digitally available within a reasonable time frame. Charles Jeurgens, 'The Scent of the Digital Archive: Dilemmas with Archive Digitisation', BMGN - Low Countries Historical Review 128:4 (2013) 30-54, 45. DOI: https://doi. org/10.18352/bmgn-lchr.9348. This 10-percentage number is also mentioned by Gerhard Hijszeler, Senior Consultant and Projectmanager at DE REE Archiefsystemen, the company that facilitates the website www.archieven.nl, in an interview I had with him (22 November 2018). geheugenvannederland.nl/nl/geheugen/pages/ collectie/Oorlogsdagboeken, accessed 14 November 2019; Huygens ING provides digital access to several egodocuments: 'Resources
Huygens ING', http://resources.huygens.knaw.

$\mathrm{nl} /$, accessed 14 November 2019; ATRIA has digitised approximately 40 egodocuments: 'Egodocumenten', https://atria.nl/bibliotheekarchief/collectie/egodocument/, accessed 14 November 2019; the Frysian archive Tresoar has made letters of Frysian emigrants available online: 'Emigranten brieven', http://digicollectie.tresoar. nl/e_brieven/, accessed 14 November 2019. 'Dagboek Willem de Clercq 1811-1844', http:// resources.huygens.knaw.nl/dagboekdeclercq, accessed 14 November 2019.

116 For example: 'Rutgers van der Loeff', http://www. rutgersvanderloeff.nl/, accessed 14 November 2019; 'Memoires (dagboeken) van Maurits Jacob van Lennep', http://vanlennep.nl/dagboeken/, accessed 14 November 2019. On 'digital materiality', see: Mats Dahlström, 'Critical Editing and Critical Digitisation', in: Wido van Peursen, Ernst Thoutenhoofd and Adriaan van der Weel (eds.), Text Comparison 
both the transcription and the image of the ego-document itself, as well as a search engine, such as that of the diary of Willem de Clercq. ${ }^{118}$ However, digitisation also has its downsides, because it always leads to a loss of information. Although the representation of visual and material aspects is better than in most printed versions, the 'scent of the archive' of the original documents is not transferable to the digital representation. ${ }^{119}$ As long as the original manuscripts are preserved, this presents no significant problems, but digitisation bears the risk of the original documents being destroyed. ${ }^{120}$

In recent decades, ego-documents have also been published in two major book series: Privé-domein (Arbeiderspers) and Egodocumenten (Verloren). The Privé-domein series, inspired by the French series Domaine privé, started in 1966. It contains ego-documents of famous writers, artists and intellectuals from the Netherlands, such as Arnon Grunberg and Annie Romein-Verschoor, and also from other countries (in Dutch translation), such as Salvador Dali, Virginia Woolf, Samuel Pepys, Arthur Schopenhauer and Claude Debussy. Currently, the series contains 305 editions. ${ }^{121}$ According to book historian Lisa Kuitert 'the whole is more than the sum of the parts'. People collect the series and reviewers often praise the entire series when reviewing a part. ${ }^{122}$ The series primarily contains memoirs ( 60 percent), a broad term referring to several kinds of autobiographical texts. The other genres are diaries (20 percent), letters (15 percent), and some miscellaneous texts. ${ }^{123}$

and Digital Creativity: The Production of Presence and Meaning in Digital Text Scholarship. Scholarly Communication 1 (Leiden 2010) 77-97. DOI: https://doi.org/10.1163/ej.9789004188655.i-328.29; Jenny Newell, ‘Old Objects, New Media: Historical Collections, Digitization and Affect', Journal of Material Culture 17:3 (2012) 287-306. DOI: https://doi.org/10.1177/1359183512453534.

'Dagboek Willem de Clercq 1811-1844', http:// resources.huygens.knaw.nl/dagboekdeclercq, accessed 14 November 2019. informational aspects, such as the structure and chemical composition of the paper and the ink, watermarks, the method of binding, weight and traces of other users. Jeurgens, 'The Scent of the Digital Archive', 40.

120 Ibidem, 39-43.

Part 305 (Willem Pijper, In het licht van de eeuwigheid. Een leven in brieven 1917-1947) was published in November 2019. The website www.privedomein.info that used to contain the catalogue of the series has disappeared. Information on the series is now provided on: https://www.facebook.com/privedomein. The website is still accessible via Wayback Machine, a digital archive of the World Wide Web: https:// web.archive.org/web/20190430052413/http:// www.privedomein.info/, accessed 14 November 2019. Nederlandse literatuur 1945-1996. Deel 4 Een vangnet voor moderne schrijvers. De triomf van de paperbackseries (Amsterdam 1997) 326-332. Some collectors wrote personal reflections about their 'collector's rage', published as 'Mijn privédomein' on the website: https://web.archive.org/ web/20190426181018/http://www.privedomein. info/archief/, accessed 14 November 2019.

123 The graphic of the percentage per genre is not entirely clear (the total sum is more than 100 percent). https://web.archive.org/ 
In contrast to the Privé-domein series, the Egodocumenten series from Verloren publishing house does not concern famous figures. The Egodocumenten series originated in 1988, in close collaboration with the inventory projects. ${ }^{124}$ It includes autobiographies, diaries, letters, travel journals and the like from the seventeenth, eighteenth and nineteenth centuries. The series contains 33 volumes and has recently come to an end, although Verloren continues to publish ego-documents. This is a pity, but it offers an opportunity to evaluate the entire series. There have been several positive reviews of parts of the series, all highly justified. ${ }^{125}$ However, the series has never been reviewed as a whole in relation to broader developments in the field of life writing, as I aim to do here.

Every part of the series has been carefully edited to academic standards. The books consist of an introduction, a transcription of the egodocument, which is annotated with explanatory notes, and some volumes include a glossary and an index of names at the end. The introductions by various editors vary in length and scope, but they all put the authors in their socio-cultural historical context and provide explanatory notes on the volume. The volumes are reproductions of the texts. In recent life writing studies, however, the focus has also shifted to these texts as artefacts: the egodocument as an object with a typical visual and material form, which offers valuable information on autobiographical practices. ${ }^{126}$ This form may be as varied as the text it contains: from the familiar pre-printed diaries and notebooks, sometimes with locks on them, to the more uncommon, but fascinating examples, such as graphic narratives, embroidery, and diaries

web/20190426181102/http://www.privedomein. info/verzamelaars/, accessed 14 November 2019.

124 'Tekstedities uitgeverij Verloren', http://www. egodocument.net/tekstedities-Verloren.html, accessed 14 November 2019; 'Series en reeksen oude series (niet meer actief)', https://verloren. $\mathrm{nl} /$ series/nbE6bqSSJf8PXZa2oqSRd3/104686/ oude-series-niet-meer-actief, accessed 14 November 2019.

125 E.g. Wim Pelt, 'N. Maas, Nederlandsche toestanden. Uit het leven van een lijder, N. Maas, ed.', BMGN - Low Countries Historical Review 113:1 (1998) 121-122. DOI: http://doi.org/10.18352/ bmgn-Ichr.4653; René Bosch, 'Een tirannieke oom in Holland', de Volkskrant, 6 April 2001, https:// www.volkskrant.nl/nieuws-achtergrond/eentirannieke-oom-in-holland b31e1241d/, accessed 14 November 2019. Selections from reviews are also visible on the website of publishing house Verloren itself: https://verloren.nl/series/ nbE6bqSSJf8PXZa2oqSRd3/104686/oude-seriesniet-meer-actief, accessed 14 November 2019.

126 Erscheinungsformen von Tagebüchern von Mädchen und Frauen im 20. Jahrhundert', L'Homme. Europäische Zeitschrift für Feministische Geschichtswissenschaft 24:2 (2013) 53-71. DOI: http://dx.doi.org/10.25595/1166; Martyn Lyons and Rita Marquilhas, 'A World Inscribed Introduction', in: Idem (eds.), Approaches to the History of Written Culture. A World Inscribed (Cham 2017) 1-20. https://link.springer.com/ chapter/10.1007/978-3-319-54136-5_1, accessed 14 November 2019; Ashplant, 'Life writing "from Below" in Europe: Authors, Archives, Avenues, Arenas', 11. 


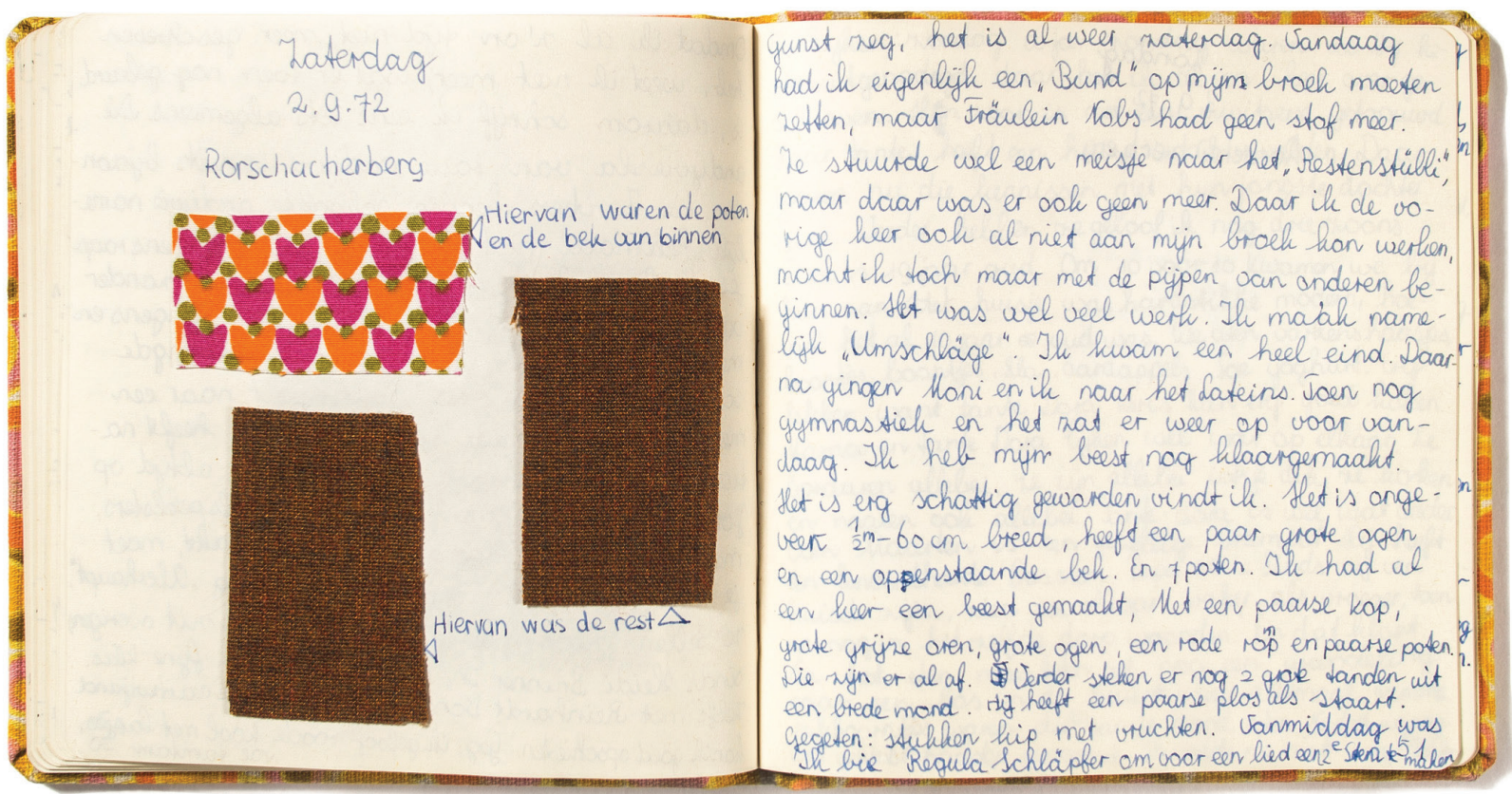

$\Delta$

This diary from the collection of the Nederlands Dagboekarchief (Dutch Diary Archive) demonstrates that these egodocuments are not only texts, but also objects with a typical visual and material form, offering valuable information on autobiographical practices. (C) Nederlands Dagboekarchief (Dutch Diary Archive) at the Meertens Institute in Amsterdam, and photographer Adrie Mouthaan. 
written on cigarette papers or on the floorboards of a French chateau. ${ }^{127}$ The Egodocumenten series does not contain such fascinating 'texts as artefacts', although an exceptional visual source in the series is the diary that Jacob de Vos illustrated for his children. ${ }^{128}$

Not only do the editions pay little attention to the texts' material and visual forms, they also could more thoroughly demonstrate that the texts themselves are more complex entities, with a life behind them. The hand-writing is sometimes shown by one sample from the text, but changes to the text, such as self-censoring, erasures or additions made by the author or by later readers (for instance deleted pages, covered parts, crossed out words, symbols, remarks in the margins) are frequently missing. ${ }^{129}$ Such information can offer valuable insights, for example into the boundaries between the public and the private spheres, into the history of the body, illness and sexuality, but also into political contexts of self-censoring and archival strategies. ${ }^{130}$ Of course, illustrations and facsimiles are costly, but the painted album of Louise Feith, which gives an impression of elite housing in the northern city of Groningen around 1900: 'Het Feithhuis, getekend door Louise Feith', https://www. deverhalenvangroningen.nl/alle-verhalen/hetfeithhuis-getekend-door-louise-feith, accessed 14 November 2019. The embroidery refers to a long letter written around 1900 by Lorina Bulwer, an inmate of the Great Yarmouth workhouse in the east of England. It was embroidered on samples of different kinds of material which she had sewn together to form a scroll of multi-coloured cloth, five metres long. Lyons and Marquilhas, 'A World Inscribed', 1. The other example refers to a tiny diary (1943-1945) written on cigarette papers by $\mathrm{H}$. Kalshoven, who was imprisoned in the Tjimahi internment camp close to Bandung. NIOD, Nederlands-Indische dagboeken en egodocumenten, cat. 401, H. Kalshoven, Dagboek, inv. 407. The final example is a hidden diary (18801881) written by a carpenter named Joachim Martin on the floorboards of a French chateau. JacquesOlivier Boudon, 'Les maires d'un canton des Hautes-Alpes vus par Joachim Martin, charpentier au château de Picomtal', Cahiers de la Méditerranée 94 (2017) 29-39, http://journals.openedition.org/ cdlm/8522, accessed 14 November 2019.
128 Eveline Koolhaas-Grosfeld, Vader \& zoons. Jacob de Vos Wzn. (1774-1844) en de getekende dagboekjes voor zijn kinderen. Egodocumenten 24 (Hilversum 2001).

129 An exception is the diary of Alexander van Goltstein, which shows symbols for masturbation. On these and other symbols, see: Vermeer, 'Tiny Symbols Tell Big Stories'. The collection of the Dutch Diary archive contains some interesting examples of self-censoring practices, such as diaries in mirror-writing, a sewn up diary, a diary with a handwritten note 'burn unread', et cetera. Leonieke Vermeer, 'Ongelezen verbranden?', 30 June 2015, https://www.

historici.nl/ongelezen-verbranden/, accessed 14 November 2019; Leonieke Vermeer, 'De mens zonder hemd. Symbolen in dagboeken als bron voor de geschiedenis van het lichaam, seksualiteit en ziekte', Groniek 49:213 (2017) 427-437. https:// ugp.rug.nl/groniek/article/view/32561/29956, accessed 14 November 2019.

130 Suzanne Bunkers and Cynthia Huff (eds.), Inscribing the Daily: Critical Essays on Women's Diaries (Amherst 1996) 2; Gustav Rene Hocke, Europäische Tagebücher aus vier Jahrhunderten: Motive und Anthologie (Frankfurt am Main 1991) 162-172; Vermeer, 'Tiny Symbols Tell Big Stories'. 


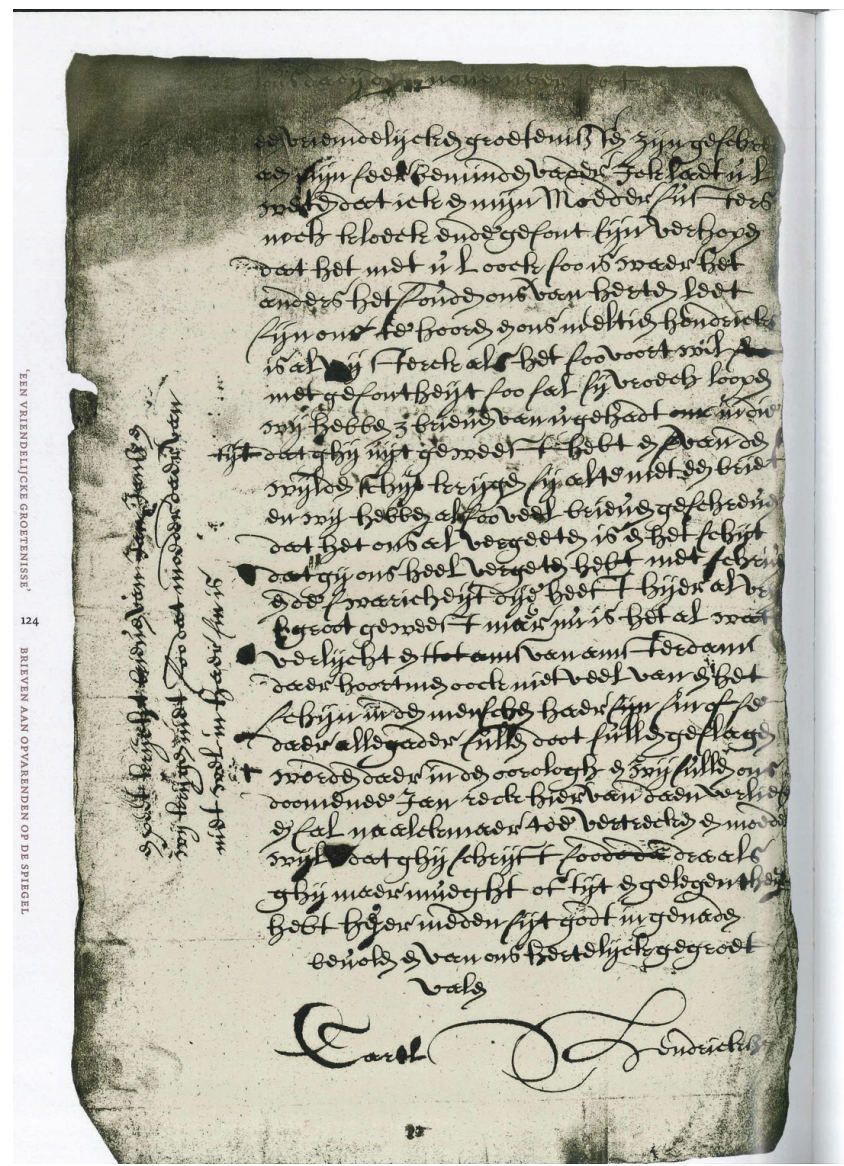

17) Brief van Carel Hendricksen aan zijn vader Hendrick Karelsen (timmerman)

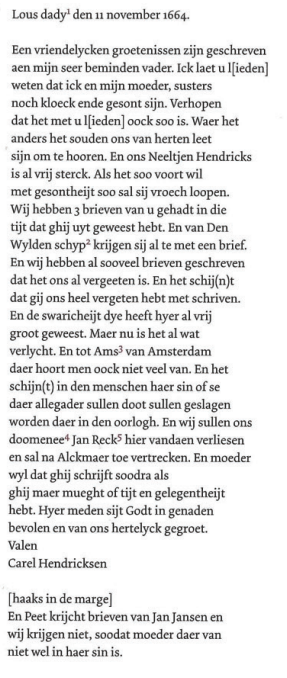

[adressering] Te bestellen aen Hendrick Karelsen, timmerman op het schip de Spiegel, met menheer De Ruyter. $M(e) t$ vrient die Godt bewaert aen daperater?

1664

Bron: $\mathrm{HCA}_{3} \mathrm{O} / 226$
Lous dady - Laus deo ady; geloofd zij God, amn schip de Provincicentur bedold wordd hier het mandeur Cideon de Wild " tot Ams" is doorgehaz Jan Reck-Johannis Reehius; was vanaf november 1655 predilikant te Edam en vertrok op g novermber

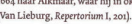
In 1632 trouwd de S Jing Hendrick Karclsen me vader, warryan word vermeld dat hij lid we was s wann Amsterdamse huistimmergilde. Zij woonden bij de

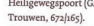
7. dapperater- niet te traceren.

$\Delta$

An example of the added value of facsimiles in the edition of the 'sailing letters': Adri van Vliet, Een 'Vriendelijcke groetenisse': Brieven van het thuisfront aan de vloot van De Ruyter (1664-1665) (Franeker 2007) 124-125. (C) Uitgeverij Van Wijnen, ISBN 9051942915. 
more attention to this material form and complicated 'biography of the text' would be justified. The added value of including facsimiles of ego-documents has been made stunningly clear in recent, successful books on remarkable letters. ${ }^{131}$

One of the great assets of the Egodocumenten series and of the inventory projects is that several texts have become part of scholarly debates, such as ego-documents by David Beck, Hermanus Verbeeck, Otto van Eck, Magdalena van Schinne and Alexander van Goltstein. ${ }^{132}$ Some reviewers of a single part of the series may doubt the historical significance of the author in question or argue that the ego-document is not 'high-quality literature'. ${ }^{133}$ However, as argued above, life writing research has widened hegemonic historiography and questioned the concept of 'representative lives'. Every individual life can be regarded as a lens through which we can view a part of history. An individual can be representative of a broader development, but can also be studied for his or her own uniqueness. ${ }^{134}$ This is also in line with the aim of the Egodocumenten series, that is, to achieve a proportionate representation of authors in terms of period, region, social origin and gender. ${ }^{135}$

Has this intention been achieved? Firstly, from the perspective of period, a majority of ego-documents (seventeen volumes) dates from the eighteenth century. In these seventeen volumes, much attention is paid to figures who were involved in the struggle between the Orangists and the Patriots at the end of this century. The seventeenth and nineteenth centuries are less well represented (with four and seven volumes respectively). The end

Deserving of a Wider Audience (Edingburgh 2013);

Shaun Usher, Letters of Note: An Eclectic Collection

of Correspondence Deserving of a Wider Audience II

(San Francisco 2016); Jet Steinz, P.S. Van liefdespost tot hatemail. De 150 opmerkelijkste Nederlandse brieven (Amsterdam 2019). Another exemplary edition of letters including facsimiles is: Adri van Vliet, Een 'Vriendelijcke groetenisse': Brieven van het thuisfront aan de vloot van De Ruyter (1664-1665) (Franeker 2007).

be concluded from citations in Google Scholar:

David Beck, Spiegel van mijn leven: een Haags dagboek uit 1624. Egodocumenten 3 (1993) (20 citations); Hermanus Verbeeck (32 citations); Otto van Eck (245 citations); Magdalena van Schinne (40 citations); Alexander van Goltstein (28 citations). Several of these studies have been mentioned in the previous section.
133 Pelt, 'N. Maas, Nederlandsche toestanden', 122; Lauran Toorians, 'Review of C.J.M. van der Heijden en J.G.M. Sanders (eds.), De levensloop van Adriaan van der Willigen (1766-1841). Een autobiografie uit een tijdperk van overgang (2010)', in: Brabant Cultureel 59:8 (2010) 28-29.

134 Sabina Loriga, 'The Plurality of the Past: Historical Time and the Rediscovery of Biography', in: Hans Renders, Binne de Haan and Jonne Harmsma (eds.), The Biographical Turn. Lives in History (Abingdon 2017) 31-41, 38. The issue of representativity in relation to biographical research has already been explored in women's studies of the 1980s: Marijke Mossink, 'Naar het leven: Een inleiding', in: Mieke Aerts et al. (eds.), Naar het leven. Feminisme en biografisch onderzoek (Amsterdam 1988) 9-27, 14-16.

135 'Tekstedities uitgeverij Verloren', http://www. egodocument.net/tekstedities-Verloren.html, accessed 14 November 2019. 


\section{MEMORIAAL}

\section{OFTE MIJN}

\section{LEVENS-}

\section{RAIJSINGHE}

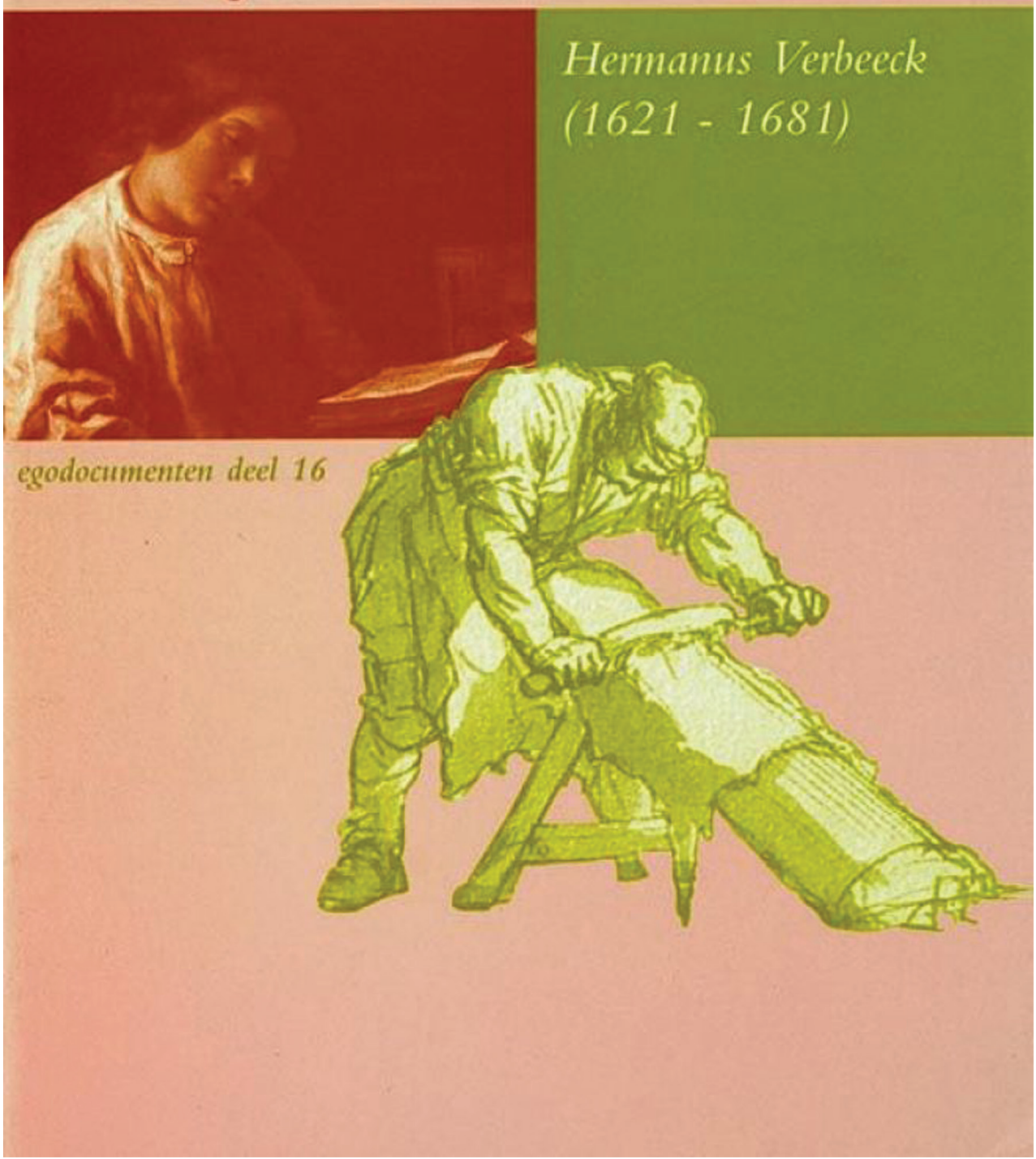

$\Delta$

Volume 16 in the Egodocumenten series of publishing house Verloren. Jeroen Blaak (ed.), Hermanus Verbeeck, Memoriaal ofte mijn levensraijsinghe. Egodocumenten 16 (Hilversum 1999). @ Uitgeverij Verloren, ISBN 90-6550-163-0. 
of the eighteenth century witnessed a large increase in autobiographical texts, so this could be one reason for the overrepresentation of this period, but only in part, because this increase continued well into the nineteenth century. ${ }^{136}$

Secondly, as to regional variety, Holland is overrepresented in the series. There are some ego-documents from people who lived in other provinces (Friesland, Gelderland, Groningen, Brabant and Zeeland), but two regions are not represented at all: Limburg and Drenthe. 'Hollandocentrism' has always been prominent in Dutch historiography, but the uneven distribution is also inherent to this kind of source material, because rural and sparsely populated regions have produced far fewer ego-documents, with the province of Friesland as an exception. ${ }^{137}$

Thirdly, in terms of the representation of different social origins, most of the published ego-documents were written by the literate elite. There are, however, some important exceptions, and it is precisely because of their rarity that these deserve to be published, such as the ego-documents of the craftsman Hermanus Verbeeck and the farmer Dirk Jansz. Nevertheless, life writing 'from below' is not very visible in the series, especially compared to the attention paid to these kind of ego-documents in other European countries, and considering that Dutch - especially Frisian - memoirs of labourers and peat workers have been of great importance for the history of the workers movement. ${ }^{138}$ This lacuna can partly be explained by the underexposure of the nineteenth century and by the absence of the twentieth century in the series. Ego-documents by women form a minority (24 percent, 6 of the 33 volumes), but this is above average by comparison with the earlier mentioned imbalance in the inventories.

In general, it can be concluded that Verloren's Egodocumenten series more or less reflects the broader picture presented by the inventory projects, including the same above mentioned imbalances inherent in this type of source material. Despite this intrinsic inequality in the distribution of sources, a series such as Egodocumenten or its successor could make more effort to 'stretch' the archive. Although there are a few ego-documents from the former Dutch colonies, for instance travel journals from South Africa and letters from the Dutch East Indies ${ }^{139}$, none of the published ego-documents

136 Lindeman et al., Egodocumenten, 11; Baggerman, 'Lost time', 462.

137 Lindeman et al., Egodocumenten, 13. A separate inventory project of Frysian egodocuments from the sixteenth century to 1940 has been held by the Fryske Akademy. Gosse Blom, Repertoarium fan egodokuminten oangeande Fryslân (Leeuwarden 1992).

138 Ashplant, 'Life Writing "from Below" in Europe: Authors, Archives, Avenues, Arenas';
Harmsen, 'De biografie in de geschiedenis van de arbeidersbeweging'; Johan Frieswijk, 'Biografische aspecten van de geschiedschrijving van de arbeidersbeweging in Friesland', It Beaken 70:3/4 (2008) 243-262. https://www.fryske-akademy.nl/ fileadmin/inhoud/beelden/homepage/Kennis/ It_Beaken/71_2009/It_Beaken_2009_1-2_13-44. pdf, accessed 14 November 2019. Carla van Baalen and Dick de Mildt (eds.), 'Weest wel met alle menschen'. De 'Kaapse Brieven' van 
have been written by enslaved persons, contract labourers or other colonised people. Such first-hand accounts are rare, but recent scholarship shows that they have been unearthed around the globe - albeit often with the aid of oral history. ${ }^{140}$ Ego-documents can even make the perspective of illiterate people visible, as the 'Sailing Letters' research project, initiated by the National Library of the Netherlands, in cooperation with the National Archives, Leiden University and Samenwerkende Maritieme Fondsen (Collaborative Maritime Funds), shows. In the seventeenth and eighteenth centuries, the English fleet captured many Dutch ships and confiscated all of the papers on board, including the private letters of sailors and passengers. These letters were often dictated by illiterate people and show traces of a variety of spoken dialects. ${ }^{141}$ Furthermore, ego-documents from patients, people with disabilities and 'wounded storytellers', written in the centuries before the 'memoir boom' of the 1990 , also deserve more attention from publishers. ${ }^{142}$

Cornelius de Jong van Rodenburgh. Egodocumenten 28 (Hilversum 2012); Gerrit Jan Schutte (ed.), Seer teder beminde Heer Vader en Vrouw Moeder! Brieven van de Groninger familie Fockens in de Oost, 17481783. Egodocumenten 30 (Hilversum 2014).

140 Pamela Pattynama, 'Herinnerd Indië:

Autobiografische teksten van Indische migrantenschrijvers', Tydskrif vir Nederlands en Afrikaans 10:2 (2004) 270-284; Margriet Fokken, Beyond being Koelies and Kantráki: Constructing Hindostani Identities in Suriname in the Era of Indenture, 1873-1921 (Groningen 2018); Étienne Naveau, 'Le propre des textes autobiographiques indonésiens', in: François-Joseph Ruggiu (ed.), The Uses of First Person Writings/Les usages des écrits du for privé. Africa, America, Asia, Europe (Brussels 2013) 77-105; Marijke Huisman, 'Beyond the Subject: Anglo-American Slave Narratives in the Netherlands, 1789-2013', European Journal of Life Writing 4 (2015). DOI: https://doi.org/10.5463/ ejlw.4.153; Yvette Kopijn and Hariëtte Mingoen, Stille passanten: levensverhalen van Javaans-

Surinaamse ouderen in Nederland (Amsterdam 2018). Barbara Henkes has combined ego-documents and oral history in her research: Barbara Henkes, Heimat in Holland: Duitse dienstmeisjes 1920-1950 (Amsterdam 1995); Barbara Henkes, “"Dan neem jij iets van die Skepper in jou eie hand": Botsende betekenissen van ras en religie in een Nederlands-
Zuid-Afrikaans verwantschapsnetwerk', in: Caspar Dullemond, Barbara Henkes and James Kennedy (eds.), 'Maar we wisten ons door de Heer geroepen': Kerk en apartheid in transnationaal perspectief (Hilversum 2017) 171-196.

141 'Sailing Letters', http://www.gahetna.nl/collectie/ index/nto0424, accessed 14 November 2019; Roelof van Gelder, Sailing letters. Verslag van een inventariserend onderzoek naar Nederlandse brieven in het archief van het High Court of Admiralty in The National Archives in Kew, Groot-Brittanië (The Hague 2006); Van Vliet, Een 'Vriendelijcke groetenisse'; Marijke van der Wal and Gijsbert Rutten (eds.), Touching the Past: Studies in the Historical Sociolinguistics of Ego-documents (Amsterdam 2013); Mascuch, Dekker and Baggerman, 'Egodocuments and History', 31.

142 Roy Porter, 'The Patient's View: Doing Medical History from Below', Theory and Society 14:2 (1985) 175-198; Thematic issue 'Body Language: Illness, Disability, and Life Writing', Life Writing 13:1 (2016). DOI: https://doi.org/10.1080/1448452 8.2016.1132376. The term 'wounded storyteller' refers to the title of an influential book on illness narratives: Arthur Frank, The Wounded Storyteller: Body, Illness, and Ethics (Chicago 1995). On Dutch ego-documents in relation to health and illness, see: Ruberg, 'The Letter'; Vermeer, “'Papa is weder ongesteld"'. See also 
All in all, the Egodocumenten series is of outstanding quality and has presented formerly unknown ego-documents both to scholars and the broader public. One can only hope that Verloren and other publishers, with the necessary aid of scholars and research funding, will continue to publish ego-documents to these academic standards. These initiatives could even gain in importance by taking discussions and insights from life writing studies into account in order to pay more attention to the variety of ego-documents as texts and artefacts 'in the making', and to ego-documents that shed light on groups and perspectives that have been underexposed in history.

\section{Conclusion}

The aim of this review article was to evaluate the Dutch inventory projects of ego-documents and their outcomes, in print and online, and situate these results in the broader context of life writing and auto/biography research in the Netherlands. Firstly, it was shown how the use of certain concepts (ego-documents, life writing, auto/biography) depends on different national traditions and the period being studied. Secondly, important research lines and discussions in the Dutch field of life writing were outlined, including the Dutch debate on biography between historians and literary scholars, and the recent plea to establish a 'crucial watershed' between biographers and life writers. However, this plea goes against current international conceptions of the auto/biographical field and against increasing interdisciplinary collaboration between historians, literary and other scholars.

Taken into consideration that the Netherlands has followed its own trajectory of auto/biographical research, with Presser's coinage of the term 'ego-documents' in the 1950 s and the pioneering inventory projects of ego-documents in the 1980 s by Dekker and others, I would argue that Dutch scholars play an important role in these collaborative efforts and in enlarging the necessary historical dimension to the field of life writing and organisations like IABA. ${ }^{143}$ The other way around, I have shown that insights from life writing studies are very valuable for the historical study of egodocuments and auto/biography.

Collaboration is also needed for the opening up and publication of ego-documents, and to face the challenges and opportunities presented by digitisation. By comparison with similar international initiatives, the Dutch inventory projects are exceptional in scope. They have brought to light an enormous number of ego-documents, of which several are very significant in an international context. Furthermore, they have formed the basis of

the Nwo-project 'Digital Disability Archive',

https://www.nwo.nl/onderzoek-en-resultaten/ onderzoeksprojecten/i/43/29943.html, accessed
14 November 2019, and the website https://www. displace.nl/, accessed 14 November 2019.

143 Cf. Huisman, 'Life Writing', 22. 
numerous auto/biographical studies on a whole range of topics, such as time and historical awareness, body history and childhood. I also discussed examples of research on the twentieth century - a period outside the scope of the inventory projects - on the Holocaust and decolonisation, to indicate crucial national and transnational public and academic debates on auto/ biographical sources.

Furthermore, I made some critical remarks and suggestions about how the digital accessibility of ego-documents could be improved. Although the database of the inventory projects has been a huge step in the right direction, one requirement for future research would be the creation of a combined and searchable web portal of ego-documents in public, private and community archives. The development of community archives, such as the Dutch Diary Archive, shows the importance of private initiatives. It also demonstrates shortcomings in the existing public archives and databases. Funding bodies like Nwo seem to prioritise digitisation above inventorisation, whereas egodocuments from the twentieth century (except from the Second World War) and ego-documents in private and community archives are not yet included in the existing databases.

Another improvement lies in the publication of ego-documents. Both digital and printed editions of ego-documents deserve high acclaim, as they make these texts more accessible, both to academics and a broader audience. Verloren has published several ego-documents from the inventory projects in its Egodocumenten series, which is of outstanding quality. Nevertheless, these and other printed editions could pay more attention to the visual and material quality of the sources and to a greater diversity of experiences.

To conclude, ego-documents are important and fascinating sources, which offer insight into a multitude of experiences and which should be studied from different perspectives using the insights of various disciplines, including historians and literary scholars. 'History and autobiography may be fated to live together as members of the same extended family', as Jeremy Popkin has put it, 'but like many family relationships, theirs will continue to be fraught with tension and a certain amount of distrust' ${ }^{144}$ This overview of auto/biographical research in the Netherlands demonstrates that the conversation between these disciplines in research projects, journals, conferences, inventorisation, digitisation and book publications, is more productive and insightful than their disciplinary demarcation. Collaboration between scholars and archivists is also a prerequisite for stretching the archive beyond its traditional constraints and opening up a wider range of autobiographical sources than before. 
Leonieke Vermeer (1975) is assistant professor of Modern History at the University of Groningen. She completed her PhD-thesis on the relationship between literature and science in 2010, which was published in the Academisch Literair series of Garant Publishers as Geestelijke lenigheid. De relatie tussen literatuur en natuurwetenschap in het werk van Frederik van Eeden en Felix Ortt, 1880-1930 (Antwerp/Apeldoorn 2011). Her recent research and publications focus on ego-documents and life writing, especially in relation to the history of the body, health and illness. She is editor of the European Journal of Life Writing and De Moderne Tijd. De Lage Landen, 1780-1940. Recent publications include: “"Cheerful Angels Looking Down on Us": Parental Emotions in Diaries about the Illness and Death of Infants and Young Children (1780-1880)', European Journal of Life Writing 7 (2018) 133-150, DOI: https://doi.org/10.5463/ejlw.7.265, and '1800. Een zeer intiem adolescentendagboek', in: Lex Heerma van Voss et al. (eds.), Wereldgeschiedenis van Nederland (Amsterdam 2018) 361-366. E-mail: L.K.Vermeer@rug.nl. 